\title{
Biases in fiscal multiplier estimates ${ }^{\text {is }}$
}

\author{
Zareh Asatryan $^{\text {a,b }}$, Annika Havlik ${ }^{\text {a,c }}$, Friedrich Heinemann ${ }^{\text {a,d,* }}$, Justus Nover ${ }^{\text {a,c }}$ \\ a ZEW Mannheim, Germany \\ ${ }^{\mathrm{b}}$ CESifo, Germany \\ c University of Mannheim, Germany \\ ${ }^{\mathrm{d}}$ University of Heidelberg, Germany
}

\section{A R T I C L E I N F O}

\section{JEL classification:}

B4

E62

H11

\section{Keywords:}

Fiscal multipliers

Meta-analysis

Economic policy ideology

Funding bias

Publication bias

\begin{abstract}
A B S T R A C T
The size of fiscal multipliers is intensively debated as large (small) multipliers provide arguments to expand (cut) public spending. We use data on multiplier estimates from over a hundred scholarly studies, and ask whether the national imprint and various incentives that the authors face can help explain the large observed variance in these estimates. We complement this metaanalytical data with information on economists' personal characteristics collected from their biographies and through a self-conducted survey. Our evidence is consistent with the hypothesis that national background and policy orientation of researchers matter for the size of multiplier estimates. We only find weak support for the hypothesis that the interests of donors financing the research are relevant. Significant biases largely disappear for teams of international co-authors.
\end{abstract}

\section{Introduction}

In this paper we ask whether the personal beliefs and career incentives of economists impact their policy-relevant research findings. In particular, we study a large sub-field of public economics that is interested in the estimation of fiscal multipliers. ${ }^{1}$ The $^{1}$ literature on fiscal multipliers is a relevant testing ground to explore our research question since multipliers can guide the appropriate level and timing of government interventions, and thus serve as crucial inputs for policy design. More specifically, we ask whether an author's national background and economic policy orientation, the financial sources funding the research, and career-related publication incentives help explain the size of fiscal multiplier estimates.

We follow Paldam (2018)'s model of an academic economist who maximizes her utility across several objectives, and hypothesize that the following three types of potential biases may play a role in explaining research results. First, economic policy preferences, partly determined by a researcher's national background, may influence her empirical findings (see Section 2.2). Saint-Paul (2018, p. 216) observes that "people seem to adopt views about underlying parameters that are conducive to the policies they would otherwise

\footnotetext{
We thank participants of the EPCS 2018, the MaTax Campus Meeting 2018, the IIPF 2018, and the Public Choice Society 2019. In particular, we thank Friedrich Schneider, two anonymous referees, and the editor Jan-Egbert Sturm for helpful comments. We gratefully acknowledge the financial support from the 2019 SEEK research program and the 2020 Open Access Publication Fund of the ZEW - Leibniz Centre for European Economic Research. Moreover, we thank Joshua Handke, Joelle Saey-Volckrick, and Marcel Wieting for excellent research assistance.

* Corresponding author. ZEW - Leibniz Centre for European Economic Research, L7 1, 68161, Mannheim, Germany. Tel.: +49 6211235149.

E-mail addresses: zareh.asatryan@zew.de (Z. Asatryan), annika.havlik@zew.de (A. Havlik), friedrich.heinemann@zew.de (F. Heinemann), justus.nover@zew.de (J. Nover).

${ }^{1}$ Multipliers are typically defined as the ratio of a change in output at a particular horizon as a response to a change in fiscal policy (see, e.g., Batini et al., 2014, and Fig. 1 for the considered types of changes). For recent work on fiscal multipliers see, e.g., Christiano et al. (2011); Ilzetzki et al. (2013); Ramey (2011, 2019).
} 
(a) Spending and Tax Reliefs

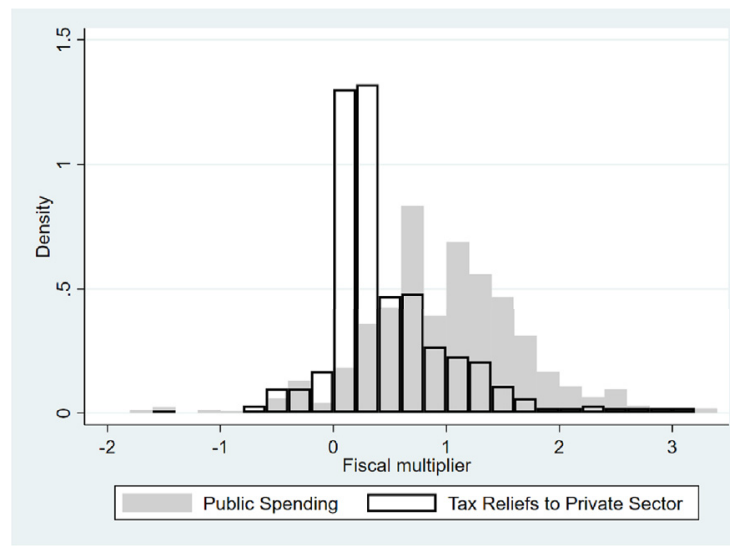

(b) Investment and Transfers

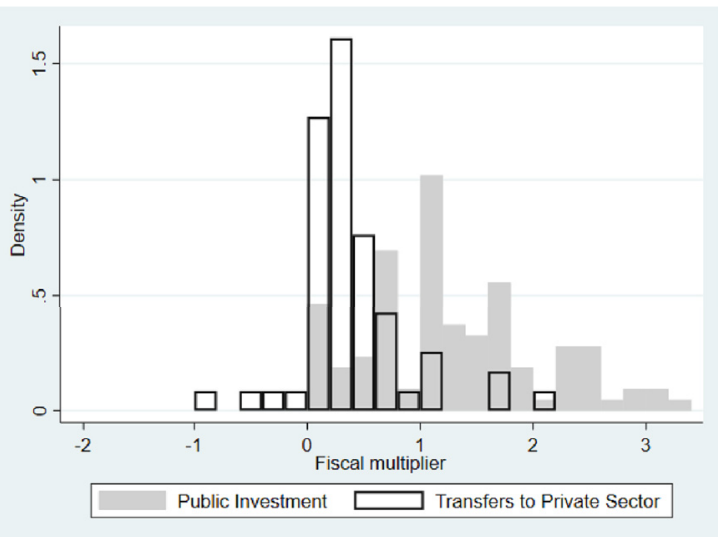

Fig. 1. Distribution of fiscal multipliers on spending and taxes (left) and investment and transfers (right). Fiscal multiplier estimates are taken from Gechert (2015). The histograms exclude outliers outside the interval of $[-1.7,3.4]$, which is three times the standard deviation around the mean value of 0.85 of the total sample. The sample includes 2283 observations of which 33 are dropped as outliers.

favor for ideological reasons", and provides anecdotal evidence for such behavior by leading US macro-economists. Moreover, there are frequent observations that contributions to macro-economic policy debates are regularly influenced by a national imprint. A country's specific economic policy experience, its dominant national schools of thought and its population's shared values may also leave its mark on researchers that originate from that specific environment (Alesina et al., 2017; Brunnermeier et al., 2016).

A second potential bias may emerge from the interests of the donors that fund the research. In pharmaceutical research, there is evidence that industry-financed studies tend to differ from independent analyses by finding more industry-favorable results (see Section 2.3). Analogous forces could be at work in macro-economic research if private donors have certain differing views on the appropriate size of government as opposed to civil servants and politicians that influence funding decisions of public donors.

A third type of bias is related to the researcher's career incentives. A well studied example of such behavior is the phenomenon of publication bias, which has been documented in various contexts (see Section 2.4). This behavior does not necessarily have an ideological dimension but may arise if reviewers and editors discriminate against insignificant or non-surprising findings.

Macro-economic research in general and fiscal multiplier literature in particular offer an especially promising field to analyze the impact of author and donor interests in research findings. The flexibility of macro-models opens rich opportunities for authors to vary assumptions on multipliers and Phillips curve trade-offs in a way that respects the internal consistency of the underlying model and its coherence with observable data (Saint-Paul, 2018). The "credibility revolution" with its emphasis on (natural) experiments is still in its infancy in macro-economic research (Leamer, 2010). Consequently, as put forward by Kirchgässner (2014, p. 1), "there is quite a lot of consensus with respect to microeconomic questions, but much less with respect to macroeconomic or macro policy questions." Ioannidis (2005) predicts that biases will be particularly large in research fields that offer a great flexibility in designs and analytical models. This condition is clearly fulfilled for multiplier research where authors have plenty of opportunity (so-called "researcher degrees of freedom", Simmons et al., 2011) to cherry-pick the method, model structure, identification strategy, data, and/or the context, among other variables of choice. This argument is consistent with Fig. 1 where we show that fiscal multiplier estimates, as collected in the meta-analysis of Gechert $(2015)^{2}$ from over a hundred scholarly studies, have a very wide distribution. ${ }^{3}$

Our data is based on this meta-data of fiscal multipliers which we augment by various author- and funding-related variables. As proxies for national imprint, we use the government-spending-to-GDP ratio and the level of economic freedom of the author's country of origin, and also rely on an author-specific preference indicator derived from a self-conducted survey among the authors of primary studies. To measure a potential funding bias, we collect data on project financing as well as study the type of a researcher's workplace. We study publication bias by testing for asymmetries in the relation between the precision and the size of the multiplier estimate, as well as by searching for systematic differences between journal articles and working papers and those between the findings of tenured and non-tenured researchers.

We find evidence that is consistent with the national and ideology bias. We do not detect any evidence for publication selection in the considered fiscal multiplier studies, and see only weak support for the hypothesis that funding sources matter. We then document evidence of factors that amplify or mitigate this distortion. We find a mitigating effect from co-author monitoring that is most pronounced for teams of international authors. We can exclude that this result is driven by a higher ranking of journals for

\footnotetext{
${ }^{2}$ Glass (1976, p.3) explains a meta-analysis to be the analysis of analyses, and defines the term as "the statistical analysis of a large collection of [...] results from individual studies for the purpose of integrating the findings". Anderson and Kichkha (2017); Nelson and Kennedy (2009); Stanley et al. (2013); Stanley (2001); Stanley and Doucouliagos (2012) present reviews of meta-analytical methods.

${ }^{3}$ Multipliers in Fig. 1 range from -0.19 to 2.27 at the bottom and top 5 percentiles of the distribution, respectively. They vary substantially across policy instruments having smaller average values for transfers (0.39) and tax cuts (0.52), and larger averages for general spending (0.97) and investment expenditures (1.27).
} 
international research teams. Our interpretation is that authors exert mutual control for professional standards so that author-teams are better able to contain biases compared to a single author. We also find some weak evidence that an author's active role in the media amplifies the ideology bias. Our interpretation is that media presence - as measured by publishing on the policy blog VoxEU - tends to identify researchers who have a "mission" and, hence, a stronger tendency to present research insights that raise public attention.

Three clarifying notes of caution are necessary. First, our approach only provides a lower bound for the possible presence of biases as our meta-analytical regression includes controls for the multiplier, model type etc., i.e., methodological decisions that may themselves be driven by author incentives. Second, if evidence for biases can be detected, this does not necessarily point to conscious manipulations (Kirchgässner, 2014). Instead, a researcher's ideological position or self-interests could impact her choice of modeling or testing approaches. Additionally, certain priors could unconsciously affect the author's trust in differing findings, thus creating a bias of judgment in the selection of results. Moreover, a financing and a publication bias can be largely outside authors' responsibility as donors and editors/reviewers may select researchers on the basis of their (past) results. The third caveat refers to causality. Our data structure does not offer an opportunity to exploit a natural experiment. Endogeneity concerns differ across hypotheses: they are more pronounced for the funding source but are smaller for the national background. The national background though is still associated with various other dimensions than just economic policy orientation, and we cannot exclude that omitted variables drive the results. Thus, we are able to show to which extent observable correlations are consistent with the existence of biases (and their antidotes) without claiming the identification of the causal channel. We continue to discuss the relevance and impact of a possible endogeneity for several of the key findings in the presentation of detailed results.

\section{Relevant literature}

\subsection{Selective publication of research results}

The first related strand of literature comprises of contributions that question the neutrality of quantitative research in economics. In an anonymous survey among members of the European Economic Association, almost half of respondents admit to present empirical findings selectively to confirm one's argument (Necker, 2014). Over recent years, meta-analytical approaches have indirectly confirmed that empirical researchers benefit from considerable discretion in selecting results and that they use this freedom. The direction of selection bias will correspond to author interests along various dimensions, such as successful publications, financial interests, and intrinsic or ideological motives (Ioannidis, 2005).

Employing a collection of 159 meta-analyses from all fields of economics, Ioannidis et al. (2017) show that most research designs suffer from low power and a consequential bias towards exaggerated effect sizes that provide significant findings despite low power. The same argument is made by Vasishth et al. (2018) who claim that publishing these low powered findings arouse a wrong impression of replicability and are a main contributor to the current "replicability crisis". Concerns are not necessarily reduced by the tendency towards more credible identification: Young (2017) claims that one third to one half of instrumental variable point estimates are wrongly declared statistically significant and replications of lab experiments are frequently unable to reproduce original findings (Camerer et al., 2016). In general, replications that cross-check published empirical results are still very rare and largely limited to high-impact articles (Mueller-Langer et al., 2019). Recent articles propose alternatives to the concept of statistical significance that should make estimates more credible (see, e.g., Gelman and Carlin, 2014; McShane et al., 2019).

The problem of exaggerated research results is especially problematic if policy-makers want to rely on these results for the implementation of new policies. Doucouliagos et al. (2018) tackle a related problem, which is challenging for policy-makers, that is "thin evidence". This term describes the issue that for new policy issues, only very few studies exist when the issue is pressing and the policy-maker has to make a decision which policy to choose and how.

With a closer link to our fiscal policy research question, Gründler and Potrafke (2019) look into the biased use of fiscal terminology. The authors demonstrate that terms like "austerity" and "fiscal consolidation" are used unequally across researchers: the former is frequently contained in articles of heterodox journals, whereas mainstream journals predominantly publish articles using the term "fiscal consolidation". The authors conclude from their analysis that the various degrees of freedom on the choice of methods and austerity measures allow "scholars to arrive at any desired results about the economic effects of austerity periods" (Gründler and Potrafke, 2019, p. 3).

\subsection{Impact of prior beliefs}

What has been established in the literature a long time ago, is the evidence on partisan politics, i.e., how different political parties have different preferences for different sets of public policies and government size (Tufte, 1978). Leftist governments often have larger public expenditure (Cusack, 1997), prefer capital over labor taxes (Angelopoulos et al., 2012), and spend more on social expenditures (Herwartz and Theilen, 2014). Relatedly, Baskaran (2011) finds that decentralization leads to higher aggregate public expenditure when the federal government is leftist instead of right-wing. With respect to individual politicians, Jochimsen and Thomasius (2014) show how a finance minister's beliefs and educational background impact on her country's deficit performance.

In an analogous way, political preferences may also impact on economic researchers who may use their discretion to produce research consistent with prior beliefs and a self-serving bias. A first relevant finding is that the significant differences in perceptions, beliefs, and economic policy preferences between economists and non-economists can to some extent be explained by the typical socio-economic status of economists (Blendon et al., 1997; Caplan, 2002): economists may have a more optimistic perspective on 
trade, liberalized labor markets, small governments, and low taxes because they are typically part of an affluent population segment with above-average incomes and low labor market risks.

Apart from the fact that economists constitute a specific sample of the population, the role of researchers' ideological biases has gained greater attention. For example, in the empirical literature on the deterrence effect of the death penalty, Kirchgässner (2014) finds evidence of an impact from prior political convictions on results, even if advanced statistical methods are applied.

The link between national tradition and economic policy preferences is another field with mounting evidence on the importance of economists' prior beliefs. These aspects have received considerable attention in a macro-context since the outbreak of the euro area debt crisis. The discussion on how to appropriately manage the crisis has revealed systematically different views among both politicians and economists from Northern and Southern Europe. Alesina et al. (2017) show that the economic integration in Europe has not reduced the heterogeneity of general norms (including the value of hard work or obedience). Guiso et al. (2016) analyze the Greek crisis and identify a cultural clash as a fundamental cause. Dyson (1999) and Brunnermeier et al. (2016) recognize a substantive divide in economic policy approaches between both economists and politicians in France and Germany. While German "ordoliberalism" stresses the importance of rules over discretion and recommends structural reforms and budgetary consolidation, French economic policy prescriptions are often more Keynesian and demand-oriented. Hien (2019) puts an emphasis on religious influence and identifies the dividing line between Northern European Protestantism and its impact on ordoliberalism and the Catholic and Orthodox Christian denominations in the South with their emphasis of unconditional solidarity. De Ville and Berckvens (2015) exploit a survey among European economists on euro area reform preferences and confirm German economists have distinct positions compared to their European colleagues.

Overall, this literature indicates that a researcher's national background is a promising proxy for her prior beliefs on the appropriate size and role of government because of a country's specific values, intellectual history and economic policy experience. However, this literature so far rests on surveys or anecdotal evidence, and largely concentrates on economic policy preferences. We add a more substantive dimension as we focus on the link between national background and actual empirical research results.

\subsection{Funding bias}

Funding-induced biases have received considerable attention in the pharmacoeconomic discipline through comparisons between publicly- and industry-financed research results on new drugs. Some examples that find a positive correlation between private sponsorship and a favorable test outcome for the pharmaceutical company are given by Friedberg et al. (1999), Baker et al. (2003), and Bell et al. (2006). Bekelman et al. (2003) review that a conflict of interest in biomedical research through financial relationships between researchers and industry alter research results. This is especially surprising as most of these studies make use of randomized control trials, which are otherwise thought of as the "gold standard" of empirical research. For a systematic overview of research on pharmaceutical industry funding and its impact on study outcomes see Sismondo (2008).

Evidence for funding biases are also seen in media studies and health economics. DellaVigna and Hermle (2014) analyze movie reviews by media outlets which are owned by a production company. Their results suggest the absence of any bias. With a similar focus but arriving at the opposite conclusion, Dobrescu et al. (2013) test the independence of book reviews when the author is connected to a media outlet. Li (2017) scrutinizes the interdependency of experts' conflict of interest and the quality of their judgment in the context of peer review at the National Institute of Health. Her findings suggest the existence of a bias in favor of projects close to the evaluators' own research.

We add to this literature on funding bias by applying it to macro-economic research. In this context, a possible funding bias is unrelated to any specific private business interest. Instead, it could be the result of public research donors' incentives and their interest in demonstrating the usefulness of public spending.

\subsection{Publication bias}

The publication bias is perhaps the most extensively researched bias in empirical economic research (De Long and Lang, 1992). It results from the competitive strive of authors for scarce space in reputed journals and can be present when referees, researchers, or editors have an ex-ante preference for statistically significant or other specific results (see, e.g., Frey (2003) for a discussion of editors' and referees' influence on research articles). Doucouliagos and Stanley (2013) find evidence for widespread and substantial publication bias in the majority of the 87 economic areas. According to their results, literatures where theory allows for a larger range of results are less selective. Their explanation is that a high community consensus on a specific theoretical prediction should make editors and reviewers more critical against empirical results contradicting this dominant theory. At the same time, they find macroeconomic research to be more prone to a selection bias than micro-research even when they control for the degree of theory consensus. Ioannidis et al. (2017) cover a wide range of fields of economics including international economics, labor economics, growth and development, microeconomics, macroeconomics, finance, and public economics. This "meta-meta-analysis" suggests that publication bias is omnipresent and is closely related to a low power of research designs that "forces" researchers to search for results until effect sizes are so large that they reach significance (Stanley and Doucouliagos, 2012).

The range of theoretical predictions for the size of fiscal multipliers is large given the long-standing macro-controversies around the existence of Ricardian Equivalence and the competition of various macro-models. This theoretical openness for different results in itself should reduce selectivity in published results (Doucouliagos and Stanley, 2013). In his meta-analysis, Gechert (2015) provides an initial analysis for a publication bias in the multiplier literature. Following standard meta-analytical methods, he hypothesizes that there should not be substantial asymmetries in the direction and magnitude of estimates which are very imprecisely estimated (small 
value for the inverse of the standard error as a measure of precision) as compared to the precisely estimated ones. Any systematic asymmetry around imprecise estimates would indicate that the published estimates are not a representative sample of the underlying population (Fig. 3 replicates this scatterplot and discusses it in more details). Gechert finds only weak evidence for a publication bias in the multiplier literature. According to these results, if such a bias exists at all, it benefits smaller multiplier estimates. This could relate to the attraction of "surprising" results. We take this as our starting point and augment Gechert's approach through tests for the impact of author-specific features that approximate different degrees of publication pressure (e.g., tenured versus non-tenured authors). If surprisingly small multipliers can catch the attention of reviewers, authors under particular publication pressure have an incentive into that direction.

\section{Hypotheses}

Our hypotheses cover three biases that relate to (i) the impact of an author's own national and ideological imprint, (ii) donor interests, and (iii) the publication process. In addition, we take account of the potential bias-enforcing effect of a researcher's involvement in media debates and the potential bias-mitigating effect of co-authorship.

With the first hypothesis, we follow the observation that a researcher's political convictions can have an impact on results (Kirchgässner, 2014; Saint-Paul, 2018). This is more likely the higher the political relevance of the parameter under scrutiny. Fiscal multipliers clearly satisfy this condition as they are important guides for economic policy decisions. In the debate on appropriate macro-economic policy, large multipliers support additional government spending and an activist fiscal policy, whereas low or even negative multipliers rather point to the merits of austerity. Should a researcher have a prior position in this debate, this might affect her impartiality. The estimates of market-liberal supply-side economists could be biased downwards while those of pro-government demand-side researchers might be biased upwards. Our main focus in the search for this ideological impact is the researcher's national background. In line with the literature on systematic differences in economic policy preferences across countries (see Section 2.2), our first hypothesis is as follows:

H1. Researchers from countries with a large government and high level of regulation present larger fiscal multiplier estimates than researchers from countries with a small government and low regulation.

Our second hypothesis deals with the possible funding bias that results from donor interests (see Section 2.3). Here, we focus on the interests of governmental institutions that fund multiplier studies directly through project grants or institutional support. From a Niskanen perspective (Niskanen, 1971, 1975), bureaucrats who steer the use of research funds might have a preference for a large government and therefore an interest in results supportive of more public spending. Even if the influence of bureaucrats on the allocation of research money is constrained in most national systems through a strong role of academic peer review, there remains room for bureaucratic influence. Elected politicians also have an interest in proving to voters a responsible and effective use of public resources. The emerging funding bias evolves through two different channels. First, the selection of researchers may favor those who are more aligned with donor preferences. Second, grant-receiving researchers might be influenced by donors in their research design as well as their choice and interpretation of results. Resulting biases are likely to differ across different types of affiliations and career ambitions (see, e.g., Paldam, 2018). Hence, our second hypothesis is:

\section{H2. Government-funded research provides larger fiscal multiplier estimates than non-government-funded research.}

The third hypothesis is about the well-known and frequently documented bias coming from publication selection (see Section 2.4). Insofar editors and reviewers prefer significant and/or surprising results, the wealth of published studies may not be representative of the underlying overall population of estimates. This may result from both editor/reviewer selection and author behavior if authors do not write up and submit "uninteresting" results in the first place.

In the context of the multiplier literature, the direction of bias is not obvious. In this literature, the crucial controversy is on the size rather than on the significance of multipliers. As mentioned in Section 2.4, Gechert (2015) finds weak evidence that the publication bias in the multiplier literature is, if anything, negative. Given these features of the multiplier literature, the search for a publication bias should target two distinctive symptoms that are, first, suspicious asymmetries in the precision of estimates around the most precise estimate (see Section 2.4) and, second, a preference for surprisingly small multipliers. The latter can be detected by comparing results from different author types (e.g., tenured vs. non-tenured researchers, as both groups differ with respect to publication incentives) or publication types (e.g., working paper vs. journal article, as a working paper represents an earlier stage of scientific production before the editor/reviewer selection sets in). Published articles or researchers with high publication pressure should provide smaller multipliers. Therefore, we construct the following hypothesis:

H3. Multiplier estimates are subject to a publication bias that leads to asymmetries in the precision of estimates and, possibly, smaller estimates in published studies (compared to working papers) and from authors with high publication pressure.

As a bias amplifier, we take account of an author's involvement in media debates. Any such activity can be taken as signal of a "mission" and, hence, a stronger policy interest. We expect that the amplifier can potentially be important for both the ideology bias (H1) and the funding bias (H2). Researchers with strong positions in public debates might also be more willing to oversell results with the help of like-minded external donors. Note that this bias does not define a genuine direction of bias. Instead, it reinforces an existing primary bias (that originates from national imprint or funding). Therefore, this amplifier is tested through an interaction of the media involvement indicator with the proxy for primary bias. We do not see any theoretical argument to expect an amplifying effect of an author's media exposure on publication bias since a high media presence is hardly an informative indicator for academic 
career ambitions and, hence, publication pressure (H3). This leads us to the following hypothesis:

H4. Active participation in the media debate on economic policy increases the effects of country imprint (H1) and financing source (H2) on multiplier estimates.

Our final hypothesis relates to a potential monitoring effect that originates from co-authorship. Several papers show that monitoring agents can decrease tax evasion or corruption. ${ }^{4}$ Moreover, it is a robust finding of the tax morale literature that singles are more likely to evade taxes than people living in marriage (Alm and Torgler, 2006). The explanation is that close social interactions have a monitoring function that tends to enforce both written and social norms. In this sense, a single agent is less constrained compared to an entity of individuals that has to agree on joint decisions. Likewise, interaction in researcher teams can be expected to activate professional norms and improve authors' respect for high scientific standards. We expect that mutual monitoring in researcher-teams should mitigate all three biases (ideology, funding, publication). There is a specific modification for the national imprint hypothesis H1. Here, we would expect a bias-reducing effect primarily from international teams. Co-authors from the same country are less likely to challenge each other on specific views that originate from the common national background. Again, our considerations for co-authorship does not suggest a primary bias but only an effect relative to existing primary biases. In contrast to the amplifier of media involvement, co-authorship should moderate the primary bias. As with H4, the detection strategy will make use of interaction terms. Hence, we evaluate the validity of the following hypothesis:

H5. Mutual monitoring from (international) co-authors reduces the biases related to the hypotheses $\mathrm{H} 1$ (national imprint), $\mathrm{H} 2$ (donor interests), and $\mathrm{H} 3$ (publication bias).

\section{Data and method}

\subsection{Data}

We construct our database by combining the meta-analytical data from Gechert (2015) with our own collection of author characteristics. Gechert's database provides 1069 observations on fiscal multiplier values taken from 104 studies from 1992 to 2012 , with the majority of studies published from 2007 onwards. These contributions furthermore come from 171 different authors. The switch from an estimate perspective (where several authors together provide one estimate) to an author-estimate perspective (treating each author-estimate combination as one separate observation) results in a total of 2283 observations.

We obtain information on authors from hand-collected CVs and personal websites. This allows us to identify the authors' country in two different definitions: the country where the author received the highest educational degree, and the country of work (at the time of publication). From the CVs, we also collect the institution of employment. From the published (working) papers, we collect information about project grants. Summary statistics for the employed variables are provided in Table A1 in the Appendix. Fig. 2 shows the distribution of authors across the countries represented in our sample.

Our proxies to test the impact of national imprint on an author's ideological stance according to $\mathrm{H} 1$ are the size of government and the degree of economic freedom. To limit issues from omitted national variables, we also add an author-specific measure. To obtain this individual score, we conducted a survey among all authors to learn more about their policy preferences in macro-policy debates. From mid-February to mid-March 2019, we contacted 159 of the authors ${ }^{5}$ and received 54 replies (34\%). ${ }^{6}$ Fig. A1 in the Appendix shows the questionnaire comprising seven statements on fiscal and monetary policy issues. Researchers could agree $(=9)$ or disagree $(=1)$ with the statements in incremental steps of 1 . Based on their responses, we calculate a dummy that classifies an author as market-orientated. ${ }^{7}$

We also employ four further data sources to obtain a proxy for the market orientation of authors that did not respond to our survey. First, we use data on petitions signed by economists and classified by Hedengren et al. (2010) as liberty-augmenting vs. liberty-reducing. Second, we hand-collect data on additional petitions and open letters. ${ }^{8}$ Third, the "(European) IGM Economic Experts Panel" surveys a large amount of economists on their opinion on different policy topics, which we use to determine their preference for market-oriented policies. ${ }^{9}$ Finally, we collect data on campaign contributions for US authors from the Federal Election Commission and code a contribution to the Republican Party as an indication of market-orientation and support for the Democratic

\footnotetext{
${ }^{4}$ See, e.g., Almunia and Lopez-Rodriguez (2018), Avis et al. (2016), Battiston et al. (2020), Bobonis et al. (2016), Ferraz and Finan (2011), Kleven et al. (2011), and Olken (2007).

${ }^{5}$ For the remaining 12 authors in our sample, we were either not able to find a valid email address or the authors passed away.

${ }^{6}$ We conduct a response analysis to evaluate the possibility of systematic differences between the samples of (non-)responding authors. While the size of multiplier estimates has no effect on individual author response, correlations with some study and author characteristics exist. We control for these variables in all specifications. Results are available upon request.

${ }^{7}$ We construct the dummy as follows: The coding of responses for questions one and six was reversed such that a higher response number indicates a more market-oriented attitude for all questions. The dummy variable was then simply coded as 1 (i.e. relatively market-oriented) if the resulting average score was above the median value.

${ }^{8}$ Petition urging Congress not to increase public spending in the light of a possible recession (USA 2009) and petition for more government spending and tax credits (USA 2010).

9 http://www.igmchicago.org/surveys/economic-stimulus, http://www.igmchicago.org/surveys/economic-stimulus-revisited, http://www.igmchicago.org/ surveys/eu-fiscal-rules, http://www.igmchicago.org/surveys/us-interest-rates.
} 
(a) Work country

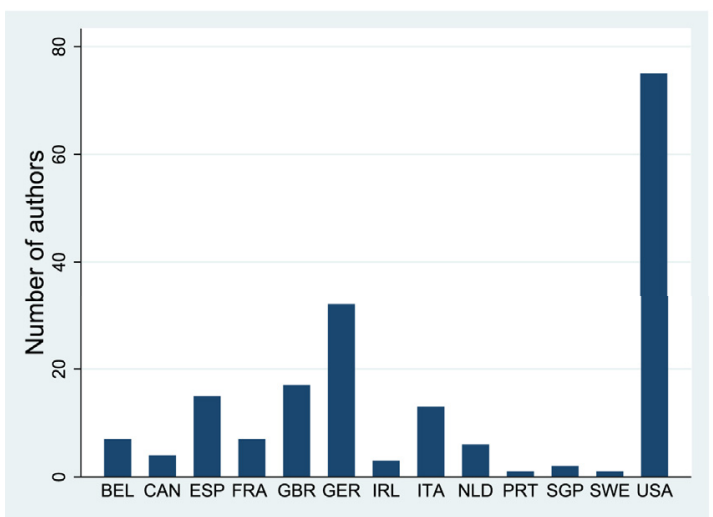

(b) Degree country

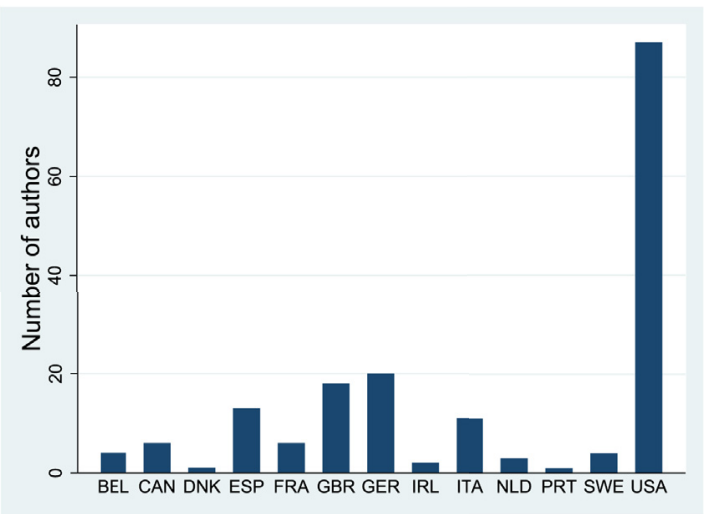

Fig. 2. Country variation. For our sample of multiplier studies, the two graphs show the number of authors working in country $x$ and having received their highest degree in country $\mathrm{x}$, respectively.

Party as a pro-government signal. ${ }^{10}$ This approach allows us to code 22 additional authors as market-versus government-oriented.

\subsection{Estimation}

We conduct a meta-analytical regression analysis to test the hypotheses developed above. Our dependent variable is the fiscal multiplier as it is derived in the underlying primary study. No further normalization is needed as this measure is already dimensionless and comparable across all studies (Gechert, 2015). ${ }^{11}$ Our unit of observation is the author-estimate. Hence, one estimate from an $n$-author team provides $n$ observations. In order to prevent studies with multiple authors to have a larger weight in the analysis, we weight each observation by the inverse of the number of authors. The resulting coefficients are weighted least squares estimates. We specify the estimation model as follows:

$$
\text { Mult }_{a i}=\beta_{0}+\beta_{1} \text { Source }_{a i}+\gamma_{1} \text { Model_X } X_{a i}+\gamma_{2} \text { Type_X }_{a i}+\gamma_{3} \text { Country }_{-} X_{a i}+\gamma_{4} X_{a i}+\varepsilon_{a i},
$$

where Mult $t_{a i}$ is our dependent variable and captures the size of the fiscal multiplier. The index $a$ denotes the author and $i$ is the particular estimate from this author. Individual researchers may be the author of several studies and many articles contain numerous estimates due to different specifications and robustness checks. The coefficient $\beta_{1}$ represents our coefficient of interest and measures the impact of the bias-inducing source. Source $e_{a i}$ can be author-dependent (e.g., national background) or study-dependent (e.g., project grant). For hypotheses $\mathrm{H} 4$ and H5, we focus on interaction effects in order to assess the substance of the claimed statements. Model_ $X_{a i}$ covers controls about the model employed in the study. ${ }^{12}{ }^{13}$ Type_ $X_{a i}$ accounts for the type of multiplier (e.g., spending or tax multiplier) with its obvious relevance for size differentials. ${ }^{14}$ Country_ $X_{a i}$ includes a battery of dummy variables for the country coverage of the underlying study. Finally, $X_{a i}$ summarizes other controls to account for the time horizon of the study and peak vs. cumulative fiscal multipliers. ${ }^{15}$ The error term is clustered at the study level.

\section{Results}

\subsection{National imprint (H1)}

To study the impact of an author's national background, we need an indicator that rates countries according to how much freemarket oriented they are. For that purpose, we make use of two proxies: the government expenditure-to-GDP ratio and the Economic Freedom of the World indicator (EFW) provided by the Fraser Institute. The EFW is an index that ranges from 0 to 10 where a higher value reflects more economic freedom. ${ }^{16}$ We measure the country indicator in the year of the (working) paper publication.

\footnotetext{
10 https://www.fec.gov/data/.

11 Fiscal multipliers are defined as the ratio of a change in output at a particular horizon as a response to a change in fiscal policy (see Fig. 1 for the considered types of changes) and are therefore perfectly comparable.

12 These include: RBC, VAR, DSGE, Macro models, and single equation estimation models.

${ }^{13}$ The type of model may matter substantially for the multiplier size. Due to their assumption on Ricardian Equivalence and market clearing, RBC models, for example, should provide systematically smaller estimates than other approaches (Gechert, 2015). See Gechert (2015) also for multiplier estimates for certain reference specifications.

${ }^{14}$ We include dummies to differentiate between multipliers for: public consumption, public investment, public military spending, public unspecified spending, tax reliefs to the private sector, transfers to households, direct public employment, and unspecified tax reliefs or spending increases.

15 Summary statistics and descriptions for all variables can be found in Table A1 in the Appendix.

${ }^{16}$ For $1950-2000$ the index is only available every 5 years. For the years in between we use a linear interpolation.
} 
For the expenditure ratio and the EFW, our national imprint hypothesis predicts a positive and negative coefficient, respectively. This represents the view that living in a more pro-market country with a smaller government reflects a government-skeptical position and causes the fiscal multipliers to be biased towards zero. The underlying assumption is one of revealed preferences: through the observable size of government and the extent of governmental interference with market processes, a country's population reveals its fundamental economic policy preferences. Thus, we are able to test whether authors, in their research, are influenced by the overall policy orientation of their country of origin. For internationally mobile researchers, "country of origin" is, of course, ambiguous. Therefore, we work with two different definitions: country of work and country of the highest educational degree.

Besides the two country indicators, we also use our author-specific survey indicator of policy orientation. This author-specific indicator provides a particularly important robustness check as a correlation between our two country indicators and the size of multipliers can be driven by omitted national variables. If results for the author indicator are similar to those for the country indicators, this signals that the empirical support for $\mathrm{H} 1$ is not merely an artifact driven by omitted national variables.

Table 1 summarizes regression results for the tests of hypothesis H1. The dependent variable is the fiscal multiplier estimate. We cluster the standard errors at the study level. Columns (1)-(4), (5)-(8), and (9)-(12) present various specifications for our three indicators of ideological orientation: expenditure ratio, economic freedom, and our author-specific indicator of ideological orientation, respectively.

For the expenditure ratio and economic freedom regressions, we provide two variants that relate those indicators to either the author's country of workplace or education. For both country definitions, an obvious endogeneity exists. First, economists (or students in economics) might migrate to those countries that offer a public sector in line with their preferences so that neither the country of education, nor of work is truly exogenous. However, this kind of endogeneity does not compromise our testing strategy. If such a Tiebout-migration does actually characterize economists' location choices (Tiebout, 1956), this would even strengthen the case that a country's governmental features are a useful proxy for author ideology.

For the author-specific dimension, we use the indicator that takes our survey results only, and the augmented one that adds data on campaign donations and other sources. All specifications are presented with and without country fixed effects. We always include the full set of control variables accounting for the type of multiplier, model, country-coverage ${ }^{17}$, and other features of the underlying study. Detailed results for all these controls are presented in Table A2 in the Appendix. ${ }^{18}$

The results are consistent with our hypothesis in all but one specification. Authors from countries with larger governments or lower economic freedom come up with larger multipliers. The same holds for authors that are classified as having a pro-government orientation through our author-specific indicator. With one exception, all specifications that use country fixed effects are estimated with high statistical precision. Effect sizes are fairly large: A 10 percentage point increase in spending-to-GDP ratio increases the fiscal multiplier by $0.07-0.47$ points on average (or $8-55 \%$ of the mean). A one point increase in the EFW indicator is associated with a decrease in the multiplier of up to 0.62 points. Lastly, the average difference between market- and government-oriented researchers amounts to a magnitude of between 0.1 and 0.21 points in the size of multipliers.

These estimated effects are based on a weighted least squares regression as is common in meta-analytical studies. Such weighting procedures are used to account for the heterogeneity in methodological approaches and sample sizes in primary studies and lead to a more efficient estimation compared to ordinary least squares (Greene, 2003). For our main results, we use weights based on the inverse of the number of authors per study as described in Section 4.2. As the appropriate choice of weights is non-trivial in our case, we re-estimate the models in Table 1 based on an alternative weight specification. Similar to Gechert (2015) and Heinemann et al. (2018), we also weight individual multiplier estimates using the inverse of the share of observations per study in relation to the full sample. By doing so, each study is given an equal weight. Results are documented in Table A3 in the Appendix and largely support our above-drawn conclusions.

Another concern regarding the results in Table 1 is their potential sensitivity to the US since a large share of researchers work or were educated in the US (see Fig. 2). Table A4 in the Appendix reports the exercise on excluding the US from the analysis. The sample shrinks by $40 \%$ and this affects the results to some degree. Importantly, the direction of the effect is unaffected when excluding the US for all of the employed ideology measures. Despite the drop in the precision of estimates, the effect remains to be statistically significant for 2 out of 5 measures.

\subsection{Funding ( $\mathrm{H} 2)$}

As formulated in $\mathrm{H} 2$, the funding bias should lead to higher multiplier estimates for government-financed studies. In the following, we test this hypothesis for direct funding through research grants and indirectly through institutional funding. Table 2 summarizes the various specifications. As in the preceding section, all regressions include the full set of control variables as previously described. Likewise, we again provide specifications with and without country fixed effects.

Columns (1) and (2) present results for the simple distinction between studies that received any type of project grant (independent of the funding source) or not (or at least without reporting the funding in the final publication). Studies that include an explicit reference to an external funding are less frequent and account for 30 out of 104 studies included. In line with the reasoning above,

\footnotetext{
17 Country fixed effects refer to author country; country-coverage controls refer to the country groups that are included in the primary study. The inclusion of the latter is a safeguard against the risk that a correlation between country origin and country coverage drives the results.

18 The point estimates of the controls for the model and multiplier type presented in Table A2 in the Appendix are in line with the findings of Gechert (2015). For example, relative to government consumption, investment multipliers are large and tax or transfer multipliers small. Among the models, RBC approaches tend to arrive at the smallest multipliers as expected.
} 
Table 1

National imprint \& individual market orientation.

\begin{tabular}{|c|c|c|c|c|c|c|c|c|c|c|c|c|}
\hline \multirow[t]{2}{*}{ Variable } & (1) & (2) & (3) & (4) & (5) & (6) & (7) & (8) & (9) & (10) & (11) & (12) \\
\hline & \multicolumn{12}{|c|}{ Fiscal multiplier estimate } \\
\hline Expenditure/GDP (workplace) & $\begin{array}{l}0.6939 \\
(0.6663)\end{array}$ & $\begin{array}{l}2.8127^{* * *} \\
(1.0205)\end{array}$ & & & & & & & & & & \\
\hline Expenditure/GDP (education) & & & $\begin{array}{l}1.1285^{*} \\
(0.6580)\end{array}$ & $\begin{array}{l}4.6641^{* * *} \\
(1.3454)\end{array}$ & & & & & & & & \\
\hline Economic freedom (workplace) & & & & & $\begin{array}{l}0.0659 \\
(0.1113)\end{array}$ & $\begin{array}{l}-0.6207^{* * *} \\
(0.2110)\end{array}$ & & & & & & \\
\hline Economic freedom (education) & & & & & & & $\begin{array}{l}-0.0795 \\
(0.1123)\end{array}$ & $\begin{array}{l}-0.5472^{* *} \\
(0.2173)\end{array}$ & & & & \\
\hline $\begin{array}{l}\text { Dummy: market orientation } \\
\text { (survey responses) }\end{array}$ & & & & & & & & & $\begin{array}{l}-0.1583^{*} \\
(0.0892)\end{array}$ & $\begin{array}{l}-0.1011 \\
(0.0763)\end{array}$ & & \\
\hline $\begin{array}{l}\text { Dummy: market orientation } \\
\text { (survey \& other sources) }\end{array}$ & & & & & & & & & & & $\begin{array}{l}-0.1820^{* *} \\
(0.0839)\end{array}$ & $\begin{array}{l}-0.2122^{* * *} \\
(0.0799)\end{array}$ \\
\hline Multiplier type controls & $x$ & $x$ & $x$ & $x$ & $x$ & $x$ & $x$ & $x$ & $x$ & $x$ & $x$ & $x$ \\
\hline Other controls & $x$ & $x$ & $x$ & $x$ & $x$ & $x$ & $x$ & $x$ & $x$ & $x$ & $x$ & $x$ \\
\hline Model controls & $x$ & $x$ & $x$ & $x$ & $x$ & $x$ & $x$ & $x$ & $x$ & $x$ & $x$ & $x$ \\
\hline Country coverage & $x$ & $x$ & $x$ & $x$ & $x$ & $x$ & $x$ & $x$ & $x$ & $x$ & $x$ & $x$ \\
\hline Country fixed effects & & $\times$ & & $\times$ & & $x$ & & $x$ & & $x$ & & $x$ \\
\hline Observations & 2250 & 2250 & 2044 & 2044 & 2250 & 2250 & 2044 & 2044 & 794 & 794 & 905 & 905 \\
\hline R-squared & 0.2692 & 0.3348 & 0.2731 & 0.3046 & 0.2677 & 0.3409 & 0.2677 & 0.2935 & 0.3386 & 0.4336 & 0.3512 & 0.4211 \\
\hline
\end{tabular}

Results for the control variables can be found in Table A2 in the Appendix. 
Table 2

\begin{tabular}{|c|c|c|c|c|c|c|}
\hline Variable & (1) & (2) & (3) & (4) & (5) & (6) \\
\hline & \multicolumn{6}{|c|}{ Fiscal multiplier estimate } \\
\hline $\begin{array}{l}\text { Project grant ( } 30 \text { out of the } 104 \\
\text { studies) }\end{array}$ & $\begin{array}{l}0.2801^{* * *} \\
(0.1067)\end{array}$ & $\begin{array}{l}0.1754^{*} \\
(0.1030)\end{array}$ & & & & \\
\hline \multicolumn{7}{|l|}{ Project grant [ref.: no grant] } \\
\hline National science funding agency & & & $\begin{array}{l}0.5397^{* * *} \\
(0.1232)\end{array}$ & $\begin{array}{l}0.4290^{* *} \\
(0.1813)\end{array}$ & & \\
\hline Government/ministry & & & $\begin{array}{l}0.0991 \\
(0.1462)\end{array}$ & $\begin{array}{l}0.1944 \\
(0.1703)\end{array}$ & & \\
\hline European Commission & & & $\begin{array}{l}0.0987 \\
(0.2222)\end{array}$ & $\begin{array}{l}-0.0139 \\
(0.1365)\end{array}$ & & \\
\hline National central bank & & & $\begin{array}{l}0.2804^{*} \\
(0.1463)\end{array}$ & $\begin{array}{l}0.2431 \\
(0.1524)\end{array}$ & & \\
\hline (Research) foundation/institute & & & $\begin{array}{l}-0.3582^{* * *} \\
(0.1321)\end{array}$ & $\begin{array}{l}-0.3752^{* *} \\
(0.1502)\end{array}$ & & \\
\hline \multicolumn{7}{|l|}{ Workplace [ref.: university] } \\
\hline Government institution & & & & & $\begin{array}{l}0.0724 \\
(0.1047)\end{array}$ & $\begin{array}{l}0.1283 \\
(0.1039)\end{array}$ \\
\hline Private institution & & & & & $\begin{array}{l}-0.0172 \\
(0.1106)\end{array}$ & $\begin{array}{l}-0.0360 \\
(0.1034)\end{array}$ \\
\hline International organization & & & & & $\begin{array}{l}-0.0210 \\
(0.0799)\end{array}$ & $\begin{array}{l}-0.0420 \\
(0.0903)\end{array}$ \\
\hline Central bank & & & & & $\begin{array}{l}-0.0240 \\
(0.0795)\end{array}$ & $\begin{array}{l}0.0708 \\
(0.0820)\end{array}$ \\
\hline Multiplier type controls & $\times$ & $\times$ & $\times$ & $\times$ & $x$ & $\times$ \\
\hline Other controls & $\times$ & $\times$ & $x$ & $x$ & $x$ & $\times$ \\
\hline Model controls & $x$ & $\times$ & $\times$ & $x$ & $x$ & $\times$ \\
\hline Country coverage & $x$ & $\times$ & $x$ & $\times$ & $x$ & $\times$ \\
\hline Country fixed effects & & $\times$ & & $\times$ & & $\times$ \\
\hline Observations & 2250 & 2250 & 2250 & 2250 & 2250 & 2250 \\
\hline R-squared & 0.2852 & 0.3333 & 0.3080 & 0.3446 & 0.2684 & 0.3299 \\
\hline
\end{tabular}

project grants seem to have a positive partial correlation with the size of the multiplier. The point estimates are statistically significant across all specifications.

In order to obtain a more detailed picture, we differentiate between the various sources for project grants in columns (3) and (4). These finer-grained results indicate that grants coming directly from national institutions (either the national government, the national science funding agencies, or the central banks) are associated with higher multiplier estimates than the reference case of unfunded studies. Interestingly, this effect is only precisely estimated for projects funded by national science agencies and partially for central banks, though not for those which received a research grant directly from the government. Grants from privately financed foundations or from research institutes are significantly associated with smaller multiplier estimates than studies without a grant. This supports the hypothesis as these donors should not share the same interest in proving the government to be efficient. ${ }^{19}$

Columns (5) and (6) look at the impact of government financing when it is given in an indirect way to finance the researchers' workplace. The reference workplace is university employment. ${ }^{20}$ The positive correlations for government and the negative for private institutions correspond to our expectations. However, all estimates lack statistical precision. The weaker link compared to project grants is not surprising since project grants offer a more direct channel for bureaucratic and political influence on research outcomes compared to institutional financing.

Overall, we find some evidence for a funding bias. As usual in the funding bias literature, we abstain from speculating on the direction of causality that drives the correlation. It is only one possible case that the source of funding has an impact on the conduct and results of a research project. It may also well be the case that a researcher's (prior) work changes her success rate in obtaining external finance.

\subsection{Publication bias (H3)}

We test for a publication bias by means of three approaches. First, we search for asymmetries in the relationship between an estimate and its precision. Second, we look for systematic differences between journal articles and working papers. Finally, we ask whether non-tenured researchers (due to higher publication pressure) come up with different estimates on average than tenured researchers. We base our second and third approach on Gechert's (2015) finding that the publication bias in the multiplier literature, if it exists, favors smaller estimates. This could be explainable by an incentive to provide surprising results in order to convince

19 The coding of identified grants into the 5 categories is depicted in Table A5 in the Appendix.

20 The coding of workplaces into the 4 categories is depicted in Table A6 in the Appendix. 


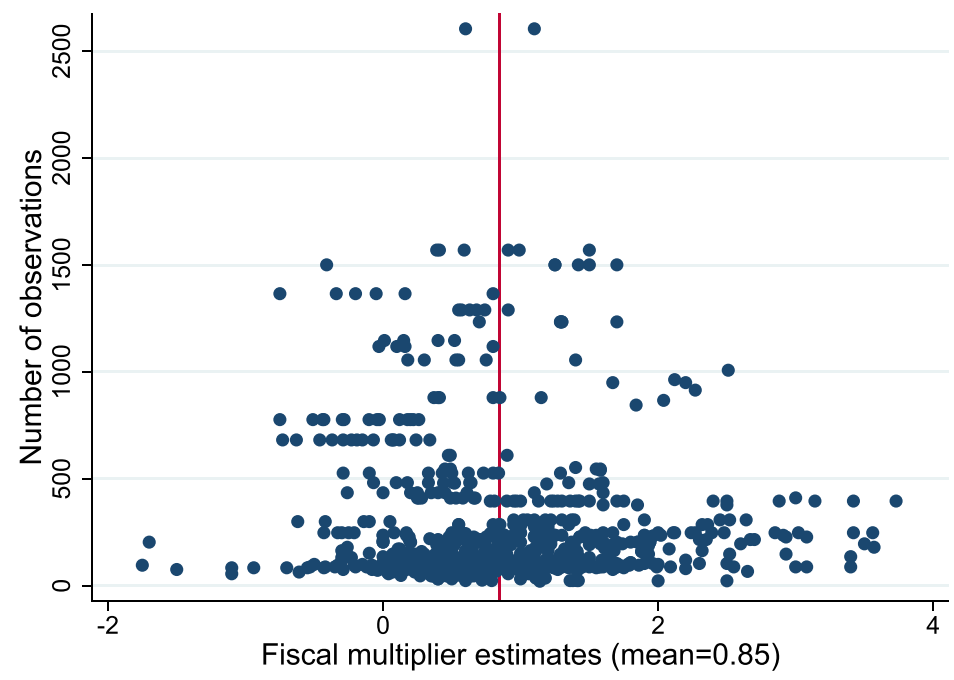

Fig. 3. Publication bias - funnel graph. The vertical red line shows the mean of the multiplier estimates in our sample which is given by 0.85 . The level of observation is study-estimate.

reviewers about the added value of another multiplier study.

To assess asymmetries in statistical precision, one would usually rely on the standard errors of the respective estimate (Doucouliagos and Stanley, 2009). However, we lack information on the standard errors of the employed studies such that, similar to Gechert (2015) and suggested by Stanley and Doucouliagos (2012), we rely on the number of observations used to obtain the multiplier estimates as a second best proxy for precision. ${ }^{21}$ We start out with a graphical investigation of the relationship between the multiplier estimates and the underlying number of observations. Fig. 3 depicts a funnel graph with the two variables. No asymmetries are visible that would point to the relevance of the publication bias in that literature.

Since any such graphical investigation is prone to subjective (mis-)interpretation, we additionally rely on an econometric analysis and estimate the following simple model similar to Doucouliagos and Stanley (2009):

$$
\text { mult }_{i}=\beta_{0}+\beta_{1} f\left(N_{i}\right)+\varepsilon_{i}
$$

where $f\left(N_{i}\right)$ are various functions of the number of observations $N_{i}$ which where used to estimate the fiscal multiplier mult in primary study $i$. The error term continues to be clustered at the study level. This testing approach relates to the interpretation of a publication bias as introducing a dependency between the standard error and the coefficient estimate, which would not exist in the absence of a bias (Stanley and Doucouliagos, 2012). Results for these asymmetry test regressions are presented in Table 3. For columns (1)-(4) and (7)-(10), a publication bias would imply statistically significant coefficients for $f(N)$. For columns (5) and (6), where also the dependent variable is weighted (by $\log (N)$ and $\sqrt{N}$, respectively), one would observe a statistically significant intercept. Since none of the specifications suggests the presence of such a bias, we do not find any significant evidence for its relevance in the underlying fiscal multiplier studies.

Columns (1) and (2) of Table 4 answer the direct question of whether the size of multipliers reported in journal articles with their entry barriers differs systematically from those in working papers or other non-journal publications. Depending on the inclusion of country fixed effects, the sign switches and results are far from being statistically significant.

Columns (3) to (6) present regression results that look into the findings of researchers that, due to safe academic positions, are under lower publication pressure compared to non-tenured colleagues. Non-tenured researchers tend to produce larger multipliers, which runs against the expectation that the publication bias would favor smaller multipliers. None of the coefficients is significant. As an alternative proxy for publication pressure, we look at researchers with a full professorship versus those without. These results again do not support the hypothesis. Overall, while we cannot prove the absence of any selection in the publication process we do not find significant support for a publication bias in the multiplier literature.

\subsection{Media involvement (H4)}

Hypothesis $\mathrm{H} 4$ claims that researchers who actively participate in media debates push their opinions in their research as well. We would then expect that both the ideological bias and the funding bias are reinforced. We therefore focus on the interaction of the H1- and H2-related variables with our indicator for media involvement. We proxy media involvement through an author's presence

\footnotetext{
${ }^{21}$ The standard errors of the multiplier estimates are not part of the original meta-analysis by Gechert (2015). This is because in some studies (i) standard errors were not reported in the primary study or (ii) multiplier estimates had to be retrieved from graphical representations of results which did not reveal (sufficient) information on the standard errors.
} 
Table 3

Publication bias - asymmetries.

\begin{tabular}{|c|c|c|c|c|c|c|c|c|c|c|}
\hline \multirow[t]{2}{*}{ Variable } & (1) & (2) & (3) & (4) & (5) & (6) & (7) & (8) & (9) & (10) \\
\hline & \multicolumn{10}{|c|}{ Fiscal multiplier estimate } \\
\hline Const. & $\begin{array}{l}0.767^{*} \\
(0.446)\end{array}$ & $\begin{array}{l}0.862^{* * *} \\
(0.151)\end{array}$ & $\begin{array}{l}0.979^{* *} \\
(0.469)\end{array}$ & $\begin{array}{l}0.906^{* * *} \\
(0.212)\end{array}$ & $\begin{array}{l}0.266 \\
(2.398)\end{array}$ & $\begin{array}{l}2.363 \\
(2.190)\end{array}$ & $\begin{array}{l}0.768 \\
(0.662)\end{array}$ & $\begin{array}{l}0.627 \\
(0.438)\end{array}$ & $\begin{array}{l}0.579^{*} \\
(0.337)\end{array}$ & $\begin{array}{l}0.648^{* * *} \\
(0.222)\end{array}$ \\
\hline$f(N)$ & $\begin{array}{l}0.012 \\
(0.086)\end{array}$ & $\begin{array}{l}-0.002 \\
(0.009)\end{array}$ & $\begin{array}{l}-0.750 \\
(2.276)\end{array}$ & $\begin{array}{l}-0.919 \\
(2.274)\end{array}$ & $\begin{array}{l}0.781 \\
(0.488)\end{array}$ & $\begin{array}{l}0.662^{* * *} \\
(0.183)\end{array}$ & $\begin{array}{l}-0.015 \\
(0.093)\end{array}$ & $\begin{array}{l}0.001 \\
(0.013)\end{array}$ & $\begin{array}{l}0.596 \\
(1.785)\end{array}$ & $\begin{array}{l}0.577 \\
(1.618)\end{array}$ \\
\hline$f(N)$-specification & $\log (N)$ & $\sqrt{N}$ & $1 / \log (N)$ & $1 / \sqrt{N}$ & $\log (N)$ & $\sqrt{N}$ & $\log (N)$ & $\sqrt{N}$ & $1 / \log (N)$ & $1 / \sqrt{N}$ \\
\hline Multiplier type controls & & & & & & & $x$ & $x$ & $x$ & $x$ \\
\hline Other controls & & & & & & & $x$ & $x$ & $x$ & $x$ \\
\hline Country coverage & & & & & & & $x$ & $x$ & $x$ & $x$ \\
\hline Country fixed effects & & & & & & & $x$ & $x$ & $x$ & $x$ \\
\hline Observations & 1616 & 1616 & 1616 & 1616 & 1616 & 1616 & 1616 & 1616 & 1616 & 1616 \\
\hline R-squared & 0.0002 & 0.0005 & 0.0011 & 0.0017 & 0.0300 & 0.1409 & 0.3293 & 0.3292 & 0.3294 & 0.3294 \\
\hline
\end{tabular}

Notes: ${ }^{* * *} \mathrm{p}<0.01,{ }^{* *} \mathrm{p}<0.05,{ }^{*} \mathrm{p}<0.1$. Standard errors are clustered by study. The models include all data-based observations (i.e., excluding non-estimated DSGE, structural Macro and RBC models) which explains the reduced sample size. For columns (1)-(4) and (7)-(10), the dependent variable is the (unweighted) fiscal multiplier estimate from the primary studies. For columns (5) and (6), we follow Stanley and Doucouliagos (2012) and also weight the dependent variable (i.e., the fiscal multiplier estimate) by $\log (N)$ and $\sqrt{N}$, respectively. 
Table 4

Publication bias - type of publication and tenure.

\begin{tabular}{|c|c|c|c|c|c|c|}
\hline \multirow[t]{2}{*}{ Variable } & (1) & (2) & (3) & (4) & (5) & (6) \\
\hline & \multicolumn{6}{|c|}{ Fiscal multiplier estimate } \\
\hline Journal publication ( $34 \%$ of studies) & $\begin{array}{l}-0.0085 \\
(0.0697)\end{array}$ & $\begin{array}{l}-0.0069 \\
(0.0632)\end{array}$ & & & & \\
\hline Tenure position ( $35 \%$ of authors) & & & $\begin{array}{l}-0.0613 \\
(0.0824)\end{array}$ & $\begin{array}{l}-0.0340 \\
(0.0619)\end{array}$ & & \\
\hline Full professorship ( $27 \%$ of authors) & & & & & $\begin{array}{l}-0.0124 \\
(0.0812)\end{array}$ & $\begin{array}{l}0.0020 \\
(0.0536)\end{array}$ \\
\hline Multiplier type controls & $x$ & $x$ & $\times$ & $x$ & $\times$ & $\times$ \\
\hline Other controls & $\times$ & $x$ & $\times$ & $\times$ & $x$ & $\times$ \\
\hline Model controls & $x$ & $x$ & $x$ & $x$ & $x$ & $\times$ \\
\hline Country coverage & $\times$ & $x$ & $\times$ & $x$ & $\times$ & $\times$ \\
\hline Country fixed effects & & $\times$ & & $\times$ & & $\times$ \\
\hline Observations & 2250 & 2250 & 1246 & 1246 & 1246 & 1246 \\
\hline R-squared & 0.2671 & 0.3279 & 0.2663 & 0.3470 & 0.2651 & 0.3467 \\
\hline
\end{tabular}

Notes: ${ }^{* * *} \mathrm{p}<0.01,{ }^{* *} \mathrm{p}<0.05,{ }^{*} \mathrm{p}<0.1$. Standard errors are clustered by study.

Table 5

Interaction media involvement with national imprint.

\begin{tabular}{|c|c|c|c|c|c|c|c|c|}
\hline \multirow[t]{2}{*}{ Variable } & (1) & (2) & (3) & (4) & (5) & (6) & (7) & (8) \\
\hline & \multicolumn{8}{|c|}{ Fiscal multiplier estimate } \\
\hline Expenditure/GDP (workplace) & $\begin{array}{l}0.4495 \\
(0.7092)\end{array}$ & $\begin{array}{l}3.0015^{* * *} \\
(1.0544)\end{array}$ & & & & & & \\
\hline Expenditure/GDP (education) & & & $\begin{array}{l}-0.0209 \\
(0.5833)\end{array}$ & $\begin{array}{l}3.5321^{* * *} \\
(1.2530)\end{array}$ & & & & \\
\hline Exp/GDP $\times$ VoxEU & $\begin{array}{l}0.6113 \\
(1.4052)\end{array}$ & $\begin{array}{l}-0.3664 \\
(0.7636)\end{array}$ & $\begin{array}{l}2.3785^{* *} \\
(1.0220)\end{array}$ & $\begin{array}{l}1.6788^{*} \\
(0.9144)\end{array}$ & & & & \\
\hline Economic freedom (workplace) & & & & & $\begin{array}{l}0.0130 \\
(0.1110)\end{array}$ & $\begin{array}{l}-0.6627^{\text {*** }} \\
(0.2143)\end{array}$ & & \\
\hline Economic freedom (education) & & & & & & & $\begin{array}{l}0.0561 \\
(0.1069)\end{array}$ & $\begin{array}{l}-0.4219^{*} \\
(0.2142)\end{array}$ \\
\hline Economic freedom $\times$ VoxEU & & & & & $\begin{array}{l}0.1115 \\
(0.2514)\end{array}$ & $\begin{array}{l}0.1343 \\
(0.1063)\end{array}$ & $\begin{array}{l}-0.2967 \\
(0.1877)\end{array}$ & $\begin{array}{l}-0.2575 \\
(0.1744)\end{array}$ \\
\hline Publication on VoxEU & $\begin{array}{l}-0.2280 \\
(0.5820)\end{array}$ & $\begin{array}{l}0.2071 \\
(0.3097)\end{array}$ & $\begin{array}{l}-0.9026^{* *} \\
(0.4401)\end{array}$ & $\begin{array}{l}-0.6467 \\
(0.3991)\end{array}$ & $\begin{array}{l}-0.8325 \\
(1.9570)\end{array}$ & $\begin{array}{l}-0.9895 \\
(0.8343)\end{array}$ & $\begin{array}{l}2.4024 \\
(1.4626)\end{array}$ & $\begin{array}{l}2.0866 \\
(1.3618)\end{array}$ \\
\hline Multiplier type controls & $\times$ & $\times$ & $\times$ & $x$ & $x$ & $x$ & $x$ & $x$ \\
\hline Other controls & $x$ & $\times$ & $x$ & $x$ & $x$ & $x$ & $x$ & $x$ \\
\hline Model controls & $x$ & $x$ & $x$ & $x$ & $x$ & $x$ & $x$ & $x$ \\
\hline Country coverage & $x$ & $\times$ & $x$ & $x$ & $x$ & $x$ & $\times$ & $x$ \\
\hline Country fixed effects & & $\times$ & & $x$ & & $\times$ & & $\times$ \\
\hline Observations & 2250 & 2250 & 2044 & 2044 & 2250 & 2250 & 2044 & 2044 \\
\hline R-squared & 0.2702 & 0.3358 & 0.2833 & 0.3085 & 0.2687 & 0.3424 & 0.2743 & 0.2978 \\
\hline
\end{tabular}

Notes: ${ }^{* * *} \mathrm{p}<0.01,{ }^{* *} \mathrm{p}<0.05,{ }^{*} \mathrm{p}<0.1$. Standard errors are clustered by study.

on the VoxEU blog. The blog was set up by the Centre for Economic Policy Research in June 2007 to promote "research-based policy analysis and commentary by leading economists". ${ }^{22}$ It has become one of the leading platforms for economic policy debates based on academic research. 70 authors in our sample have already published on VoxEU. ${ }^{23}$

Table 5 reports the results for the H1-related ideology variables. The coefficient estimates for the interaction terms show the expected sign for only five of the eight specifications. For models (1) to (4), a positive coefficient is in line with our hypothesis and suggests that authors from countries with higher government spending show even larger multipliers if they are present in the public debate. With statistical significance, this is the case for the educational definition of author origin. For the interaction with the economic freedom indicator in models (5) to (8), we again find the expected (negative) sign for the country of education but without statistical significance. ${ }^{24}$ Results are therefore mixed and provide only indicative evidence for an amplifying effect of media involvement.

Table 6 illustrates the interaction between media involvement and the funding bias. The findings do not provide for a strong confirmation of the hypothesis. The key interaction is insignificant for grants in general (columns (1) and (2)). Looking at specific

\footnotetext{
22 voxeu.org/pages/about-vox.

${ }^{23}$ From these 70 authors, 34 are non-European in the workplace definition. This number even rises to 42 in the education definition. We experimented with Twitter activity as an alternative measure of media involvement. Due to a low number of authors active on this channel, resulting estimates are inconclusive (obtainable from the authors).

${ }^{24}$ Figs. A2 and A3 plot the overall marginal effect of media involvement on the multiplier estimates for different levels of government size and economic freedom. We do not have an ex ante expectation about this overall effect and the graphs also do not show any robust systematic relationships.
} 
Table 6

Interaction media involvement with funding.

\begin{tabular}{|c|c|c|c|c|c|c|}
\hline \multirow[t]{2}{*}{ Variable } & (1) & (2) & (3) & (4) & (5) & (6) \\
\hline & \multicolumn{6}{|c|}{ Fiscal multiplier estimate } \\
\hline Project grant & $\begin{array}{l}0.3508^{* *} \\
(0.1592)\end{array}$ & $\begin{array}{l}0.2497^{*} \\
(0.1458)\end{array}$ & & & & \\
\hline Project grant $\times$ VoxEU & $\begin{array}{l}-0.1022 \\
(0.1621)\end{array}$ & $\begin{array}{l}-0.1318 \\
(0.1489)\end{array}$ & & & & \\
\hline \multicolumn{7}{|l|}{ Grant category [ref.: no grant] } \\
\hline National science funding agency & & & $\begin{array}{l}0.7021^{* *} \\
(0.3007)\end{array}$ & $\begin{array}{l}0.5360^{*} \\
(0.3032)\end{array}$ & & \\
\hline interaction with VoxEU & & & $\begin{array}{l}-0.2060 \\
(0.3124)\end{array}$ & $\begin{array}{c}-0.1654 \\
(0.3148)\end{array}$ & & \\
\hline Government/ministry & & & $\begin{array}{l}-0.0254 \\
(0.1378)\end{array}$ & $\begin{array}{l}-0.0433 \\
(0.1465)\end{array}$ & & \\
\hline interaction with VoxEU & & & $\begin{array}{l}0.1900 \\
(0.1986)\end{array}$ & $\begin{array}{l}0.3187 \\
(0.2147)\end{array}$ & & \\
\hline European Commission & & & $\begin{array}{l}0.0944 \\
(0.2203)\end{array}$ & $\begin{array}{l}-0.0279 \\
(0.1320)\end{array}$ & & \\
\hline National central bank & & & $\begin{array}{l}0.1745 \\
(0.1650)\end{array}$ & $\begin{array}{l}0.1252 \\
(0.1801)\end{array}$ & & \\
\hline (Research) foundation/institute & & & $\begin{array}{l}-0.0145 \\
(0.1736)\end{array}$ & $\begin{array}{l}0.0656 \\
(0.1902)\end{array}$ & & \\
\hline interaction with VoxEU & & & $\begin{array}{l}-0.3993^{*} \\
(0.2271)\end{array}$ & $\begin{array}{l}-0.5077^{*} \\
(0.2664)\end{array}$ & & \\
\hline \multicolumn{7}{|l|}{ Workplace [ref.: university] } \\
\hline Government institution & & & & & $\begin{array}{l}0.1353 \\
(0.1197)\end{array}$ & $\begin{array}{l}0.1907^{*} \\
(0.1051)\end{array}$ \\
\hline Private institution & & & & & $\begin{array}{l}0.0130 \\
(0.1156)\end{array}$ & $\begin{array}{l}0.0067 \\
(0.1132)\end{array}$ \\
\hline International organization & & & & & $\begin{array}{l}-0.0108 \\
(0.0787)\end{array}$ & $\begin{array}{l}-0.0244 \\
(0.0961)\end{array}$ \\
\hline Central bank & & & & & $\begin{array}{l}-0.0032 \\
(0.0732)\end{array}$ & $\begin{array}{l}0.1023 \\
(0.0842)\end{array}$ \\
\hline Government institution $\times$ VoxEU & & & & & $\begin{array}{l}-0.2081 \\
(0.1432)\end{array}$ & $\begin{array}{c}-0.2585^{*} \\
(0.1354)\end{array}$ \\
\hline Publication on VoxEU & $\begin{array}{l}0.0001 \\
(0.0859)\end{array}$ & $\begin{array}{l}0.0378 \\
(0.0630)\end{array}$ & $\begin{array}{l}-0.0048 \\
(0.0829)\end{array}$ & $\begin{array}{l}0.0472 \\
(0.0600)\end{array}$ & $\begin{array}{l}0.0516 \\
(0.0727)\end{array}$ & $\begin{array}{l}0.0792 \\
(0.0581)\end{array}$ \\
\hline Multiplier type controls & $\times$ & $\times$ & $\times$ & $\times$ & $\times$ & $x$ \\
\hline Other controls & $\times$ & $x$ & $x$ & $x$ & $x$ & $x$ \\
\hline Model controls & $\times$ & $\times$ & $\times$ & $x$ & $\times$ & $x$ \\
\hline Country coverage & $x$ & $x$ & $x$ & $x$ & $x$ & $x$ \\
\hline Country fixed effects & & $\times$ & & $\times$ & & $\times$ \\
\hline Observations & 2250 & 2250 & 2250 & 2250 & 2250 & 2250 \\
\hline R-squared & 0.2860 & 0.3342 & 0.3109 & 0.3471 & 0.2699 & 0.3324 \\
\hline
\end{tabular}

Notes: ${ }^{* *} \mathrm{p}<0.01,{ }^{* *} \mathrm{p}<0.05,{ }^{*} \mathrm{p}<0.1$. Standard errors are clustered by study.

funding sources (columns (3) and (4)), only the interaction with private donors yields a significant estimate with the expected sign. Concerning the workplace perspective (columns (5) and (6)), the interactions rather point to a bias-moderating role: authors from government institutions who publish on VoxEU show a diminished tendency to come up with large multipliers.

\subsection{Co-authorship (H5)}

In this final section, we summarize the evidence on the bias-mitigating effects of co-authorship. We limit the analysis to the ideological bias $\mathrm{H} 1$ and the funding bias H2. Since we could not detect any hint of the existence of a publication bias, the search for a counterbalancing effect from coauthors becomes redundant. Like for media involvement above, we are merely interested in the bias-modifying effect of co-authorship and have no theoretical expectation for its direct impact on empirical results. Therefore, we focus our attention on the coefficient for the interaction of co-authorship with the bias-indicators.

We start with the ideological bias. We expect that monitoring from international author teams should be particularly effective in mitigating an ideological bias compared to purely national collaborations. Table 7 makes use of a dummy for authors coming from different countries. The effect of co-author monitoring is indeed highly visible and significant through all specifications that assign author preferences to their country of education. In all cases, the interaction counterbalances the original direction of the bias to a 
Table 7

Interaction co-authorship with national imprint, authors from different countries.

\begin{tabular}{|c|c|c|c|c|c|c|c|c|}
\hline \multirow[t]{2}{*}{ Variable } & (1) & (2) & (3) & (4) & $(5)$ & (6) & (7) & (8) \\
\hline & \multicolumn{8}{|c|}{ Fiscal multiplier estimate } \\
\hline $\begin{array}{l}\text { Expenditure/GDP } \\
\text { (workplace) }\end{array}$ & $\begin{array}{l}1.1192 \\
(0.8266)\end{array}$ & $\begin{array}{l}2.7700^{* *} \\
(1.0767)\end{array}$ & & & & & & \\
\hline $\begin{array}{l}\text { Expenditure/GDP } \\
\text { (education) }\end{array}$ & & & $\begin{array}{l}2.8092^{* * *} \\
(0.9453)\end{array}$ & $\begin{array}{l}5.7708^{* * *} \\
(1.4015)\end{array}$ & & & & \\
\hline $\begin{array}{l}\text { Exp/GDP } \times \text { mult. } \\
\text { authors } \\
\text { from different countries }\end{array}$ & $\begin{array}{l}-1.7665^{*} \\
(0.9805)\end{array}$ & $\begin{array}{l}0.2588 \\
(0.9292)\end{array}$ & $\begin{array}{l}-3.3821^{* * *} \\
(1.0260)\end{array}$ & $\begin{array}{l}-3.6312^{* * *} \\
(1.1825)\end{array}$ & & & & \\
\hline $\begin{array}{l}\text { Economic freedom } \\
\text { (workplace) }\end{array}$ & & & & & $\begin{array}{l}-0.0043 \\
(0.1667)\end{array}$ & $\begin{array}{l}-0.6084^{* * *} \\
(0.2205)\end{array}$ & & \\
\hline $\begin{array}{l}\text { Economic freedom } \\
\text { (education) }\end{array}$ & & & & & & & $\begin{array}{l}-0.3752^{* *} \\
(0.1782)\end{array}$ & $\begin{array}{l}-0.7213^{* * *} \\
(0.2347)\end{array}$ \\
\hline $\begin{array}{l}\text { Economic } \\
\text { freedom } \times \text { mult. authors }\end{array}$ & & & & & 0.1458 & -0.0378 & $0.5812^{* * *}$ & $0.5034^{* * *}$ \\
\hline from different countries & & & & & $(0.1849)$ & $(0.1448)$ & $(0.1965)$ & $(0.1881)$ \\
\hline Multiple authors from & 0.6726 & -0.0960 & $1.4144^{* * *}$ & $1.5388^{* * *}$ & -1.2044 & 0.2783 & $-4.5322^{* * *}$ & $-3.8932^{* *}$ \\
\hline different countries & $(0.4272)$ & $(0.3961)$ & $(0.4337)$ & $(0.4764)$ & $(1.4379)$ & $(1.1177)$ & $(1.5442)$ & $(1.4864)$ \\
\hline Multiplier type controls & $x$ & $\times$ & $\times$ & $x$ & $\times$ & $\times$ & $\times$ & $x$ \\
\hline Other controls & $\times$ & $x$ & $x$ & $x$ & $x$ & $\times$ & $\times$ & $x$ \\
\hline Model controls & $\times$ & $x$ & $x$ & $x$ & $x$ & $\times$ & $\times$ & $x$ \\
\hline Country coverage & $x$ & $x$ & $x$ & $x$ & $x$ & $x$ & $\times$ & $x$ \\
\hline Country fixed effects & & $x$ & & $\times$ & & $\times$ & & $\times$ \\
\hline Observations & 2250 & 2250 & 2044 & 2044 & 2250 & 2250 & 2044 & 2044 \\
\hline R-squared & 0.2746 & 0.3349 & 0.2882 & 0.3157 & 0.2707 & 0.3409 & 0.2845 & 0.3051 \\
\hline
\end{tabular}

Notes: ${ }^{* * *} \mathrm{p}<0.01,{ }^{* *} \mathrm{p}<0.05,{ }^{*} \mathrm{p}<0.1$. Standard errors are clustered by study.

large extent and with a high statistical significance. ${ }^{25} 26$

As collaboration of (international) authors appears to be helpful in containing biases from one's national background, mutual monitoring and exchange may equally serve to reduce funding biases. We test for this mitigating effect by interacting our monitoring dummy for the presence of co-authorships with funding indicators (Table 8). For aggregated (columns (1) and (2)) and disaggregated project grants (columns (3) and (4)), the monitoring dummy identifies multiple authors from different countries. For the workplace definition, the monitoring variable is a dummy for multiple authors (columns (5) and (6)) or for teams with at least one co-author working at a non-government institution (columns (7) and (8)).

For aggregate grants, no significant impact of co-authorship emerges, though there is a clear pattern in line with our expectations for the disaggregation. International co-authorship out-balances the impact of both government grants and private grants on the size of multiplier estimates. More specifically, the signs of the interaction coefficients are reversed compared to the plain effects and the magnitude of the counter-balancing effect is sufficient to neutralize the bias. Similar clear effects cannot be detected for the workplace analysis. However, the absence of a moderating effect is of less relevance given that there was no strong evidence for the existence of a workplace effect at all.

Our findings on multiple authors and biases might not necessarily reflect a causal impact of co-authorship. An alternative explanation is that more biased authors may self-select into single-authorship. No matter which of these mechanisms drive the results, the essential finding is that multiplier estimates of (international) author teams tend to show less symptoms of an ideological and funding bias.

\section{Conclusion}

It is well known that fiscal multiplier estimates vary largely because of different country contexts, multiplier types, or econometric models. Our contribution is that we shed light on more subjective reasons behind the observed variance of estimates related to authors' ideology, incentive effects of external research funding, and rules of the academic publication process. We find that the variance of multiplier estimates can indeed be better explained if we take account of author-specific characteristics.

We show that a researcher's economic policy orientation correlates with her estimated multipliers. This result also survives if we replace the country indicators by individual survey-based author indicators. The latter is important since our country indicator regressions could obviously suffer from an omitted variable bias. In addition, our evidence is consistent with the hypothesis that government-financed projects are associated with larger multipliers. Our analysis does not detect evidence for a publication bias in this strand of literature. The analysis delivers some evidence that researchers with an active involvement in media debates are

\footnotetext{
${ }_{25}$ Table A7 in the Appendix presents results for a multiple author dummy, irrespective of country composition. Interactions have the right sign but often fail to be significant.

${ }^{26}$ To rule out the possibility that international researcher teams publish in higher ranked and potentially less biased journals, as a robustness check we also control for publication status and journal impact factor. Our conclusions are robust to this extension. Results are available upon request.
} 
Table 8

Interaction co-authorship with funding.

\begin{tabular}{|c|c|c|c|c|c|c|c|c|}
\hline Variable & \multicolumn{8}{|c|}{ Fiscal multiplier estimate } \\
\hline Project grant & $\begin{array}{l}0.3154^{* *} \\
(0.1322)\end{array}$ & $\begin{array}{l}0.1966 \\
(0.1243)\end{array}$ & & & & & & \\
\hline Project grant $\times$ monitoring & $\begin{array}{l}-0.1944 \\
(0.1615)\end{array}$ & $\begin{array}{l}-0.0799 \\
(0.1632)\end{array}$ & & & & & & \\
\hline \multicolumn{9}{|l|}{ Grant category [ref.: no grant] } \\
\hline National science funding agency & & & $\begin{array}{l}0.6089^{* * *} \\
(0.1320)\end{array}$ & $\begin{array}{l}0.5669^{* * *} \\
(0.2059)\end{array}$ & & & & \\
\hline interaction with monitoring & & & $\begin{array}{l}-0.8717^{* * *} \\
(0.3279)\end{array}$ & $\begin{array}{l}-0.8843^{* *} \\
(0.4146)\end{array}$ & & & & \\
\hline Government/ministry & & & $\begin{array}{l}0.1328 \\
(0.1732)\end{array}$ & $\begin{array}{l}0.2537 \\
(0.2047)\end{array}$ & & & & \\
\hline interaction with monitoring & & & $\begin{array}{l}0.1957 \\
(0.2403)\end{array}$ & $\begin{array}{l}0.2649 \\
(0.2515)\end{array}$ & & & & \\
\hline European Commission & & & $\begin{array}{l}0.0735 \\
(0.2355)\end{array}$ & $\begin{array}{l}-0.0250 \\
(0.1323)\end{array}$ & & & & \\
\hline National central bank & & & $\begin{array}{l}-0.0400 \\
(0.1207)\end{array}$ & $\begin{array}{l}-0.1774 \\
(0.1409)\end{array}$ & & & & \\
\hline $\begin{array}{l}\text { (Research) foundation/ } \\
\text { institute } \\
\text { interaction with monitoring }\end{array}$ & & & $\begin{array}{l}-0.5014^{* * *} \\
(0.1552) \\
0.3765^{* *} \\
(0.1728)\end{array}$ & $\begin{array}{l}-0.5389^{* * *} \\
(0.1984) \\
0.3511^{*} \\
(0.2015)\end{array}$ & & & & \\
\hline \multicolumn{9}{|l|}{ Workplace [ref.: university] } \\
\hline Government institution & & & & & $\begin{array}{l}0.1958 \\
(0.1820)\end{array}$ & $\begin{array}{l}0.1997 \\
(0.1777)\end{array}$ & $\begin{array}{l}0.0676 \\
(0.1119)\end{array}$ & $\begin{array}{l}0.0672 \\
(0.1290)\end{array}$ \\
\hline Private institution & & & & & $\begin{array}{l}-0.0048 \\
(0.1202)\end{array}$ & $\begin{array}{l}-0.0332 \\
(0.1053)\end{array}$ & $\begin{array}{l}-0.0173 \\
(0.1111)\end{array}$ & $\begin{array}{l}-0.0399 \\
(0.1034)\end{array}$ \\
\hline International organization & & & & & $\begin{array}{l}-0.0003 \\
(0.0906)\end{array}$ & $\begin{array}{l}-0.0452 \\
(0.0913)\end{array}$ & $\begin{array}{l}-0.0204 \\
(0.0802)\end{array}$ & $\begin{array}{l}-0.0464 \\
(0.0919)\end{array}$ \\
\hline Central bank & & & & & $\begin{array}{l}-0.0402 \\
(0.0715)\end{array}$ & $\begin{array}{l}0.0734 \\
(0.0842)\end{array}$ & $\begin{array}{l}-0.0276 \\
(0.0797)\end{array}$ & $\begin{array}{l}0.0694 \\
(0.0824)\end{array}$ \\
\hline Gov. institution $\times$ monitoring & & & & & $\begin{array}{l}-0.2503 \\
(0.1987)\end{array}$ & $\begin{array}{l}-0.1174 \\
(0.1864)\end{array}$ & $\begin{array}{l}-0.0557 \\
(0.1034)\end{array}$ & $\begin{array}{l}0.1348 \\
(0.1384)\end{array}$ \\
\hline Monitoring variable & $\begin{array}{l}-0.0497 \\
(0.0864)\end{array}$ & $\begin{array}{l}0.0221 \\
(0.0825)\end{array}$ & $\begin{array}{l}-0.0636 \\
(0.0880)\end{array}$ & $\begin{array}{l}-0.0012 \\
(0.0830)\end{array}$ & $\begin{array}{l}0.0694 \\
(0.1255)\end{array}$ & $\begin{array}{l}-0.0034 \\
(0.1072)\end{array}$ & $\begin{array}{l}0.1177 \\
(0.0787)\end{array}$ & $\begin{array}{l}0.1301^{*} \\
(0.0687)\end{array}$ \\
\hline Definition monitoring & & iple autho & from diff. Cou & tries] & [multiple & ors] & [non-gov & 1thor] \\
\hline Multiplier type controls & $\times$ & $\times$ & $\times$ & $\times$ & $\times$ & $\times$ & $\times$ & $\times$ \\
\hline Other controls & $x$ & $\times$ & $\times$ & $x$ & $x$ & $x$ & $x$ & $x$ \\
\hline Model controls & $x$ & $\times$ & $x$ & $x$ & $\times$ & $\times$ & $x$ & $x$ \\
\hline Country coverage & $x$ & $\times$ & $x$ & $x$ & $x$ & $x$ & $x$ & $x$ \\
\hline Country fixed effects & & $\times$ & & $\times$ & & $\times$ & & $\times$ \\
\hline Observations & 2250 & 2250 & 2250 & 2250 & 2250 & 2250 & 2250 & 2250 \\
\hline R-squared & 0.2886 & 0.3335 & 0.3190 & 0.3532 & 0.2710 & 0.3304 & 0.2687 & 0.3308 \\
\hline
\end{tabular}

Notes: ${ }^{* * *} \mathrm{p}<0.01,{ }^{* *} \mathrm{p}<0.05,{ }^{*} \mathrm{p}<0.1$. Standard errors are clustered by study.

particularly prone to the production of multipliers that support their prior (national) beliefs on the role of government.

This work underlines the need for great caution and scientific neutrality when designing research projects. Moreover, it emphasizes that it is important for policy makers to carefully compare various sources when seeking guidance from empirical research and to take into account the conditions and schools of thought under which research projects were conducted.

Our results also suggest that co-authorship in general, and international teams in particular, are an antidote to the distorting effects of national or funding biases. If this particular insight from our results can also be applied to other strands of literature, this would carry great significance for economics in general. Of most significance in this case is the conclusion that biases, which originate from the narrowness of national debates, might be counterbalanced through more international collaboration and mutual surveillance of research teams. 


\section{Appendix}

\section{Do you agree with the following statements?}

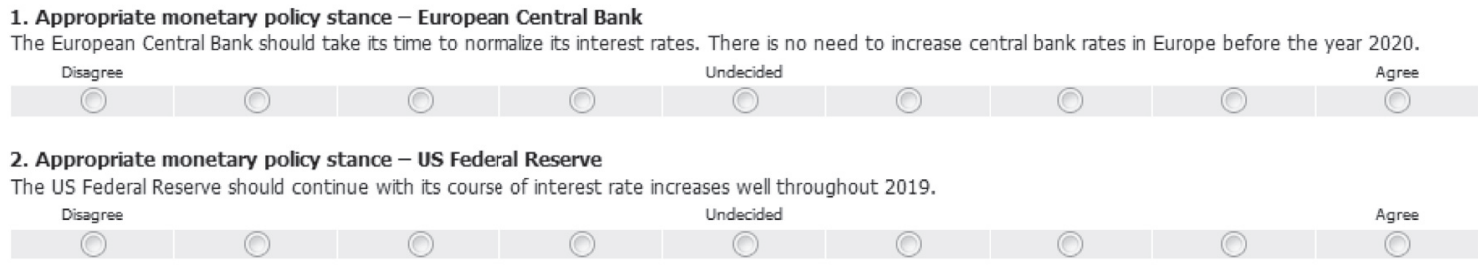

\section{Appropriate fiscal policy stance}

Overall, the current economic situation in industrial countries allows more fiscal consolidation. OECD countries should consolidate more and try to reduce government debt.

Disegree

(1)
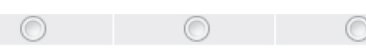

Undecided

Agree

\section{Need for privatization}

In general, the large involvement of governments in market activities still impairs the growth potential of industrial countries. Privatization should be one of the priorities in strategies to boost the growth potential in OECD countries.
Disagree
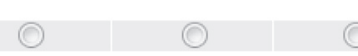
Undecided
Agree

\section{Extent of labor market regulation}

High long-run unemployment in some OECD countries largely reflects an excessive level of labor market regulation. In order to reduce this unemployment, countries would have to deregulate labor markets.
Disagree
(1)
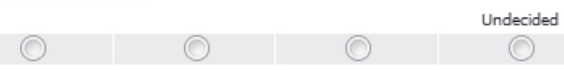

\section{Redistribution}

Current inequalities in OECD countries are not just a fairness issue but also detrimental for the growth potentia. Governments should address these inequalities by more intense redistribution.

$$
\text { Disagree }
$$

\section{Fiscal Rules}

Fiscal rules like the European Stability and Growth Pact constrain government on the size of the government deficit. Rules like this may not be perfectly effective but, in principle, they are helpful and support long-run economic stability.
Disagree

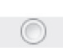
Undecided

Fig. A1 Survey questions - overview.

(a) Country of work

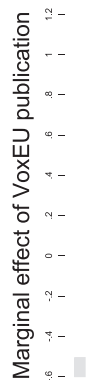

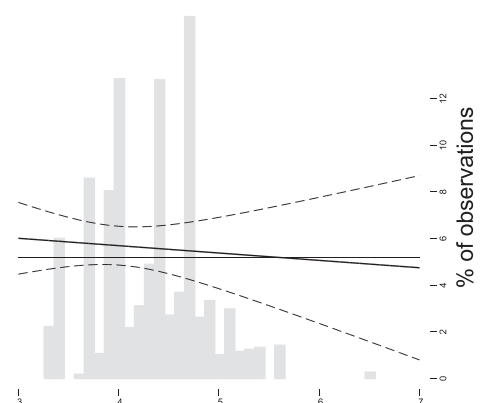

Gov. expenditure/GDP (country of work) (b) Country of highest degree

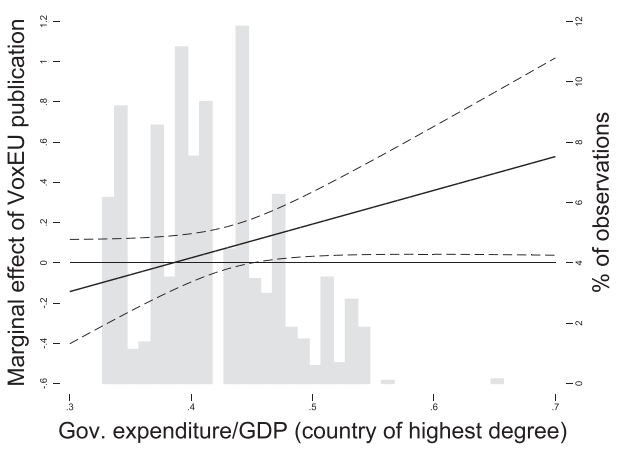

Fig. A2 Marginal effects plots, interaction media involvement with expenditure level. The graphs show the marginal effects of the VoxEU variable on the multiplier estimates. The regressions include country fixed effects and correspond to specifications (2) and (4) of Table 5, respectively. 
(a) Country of work

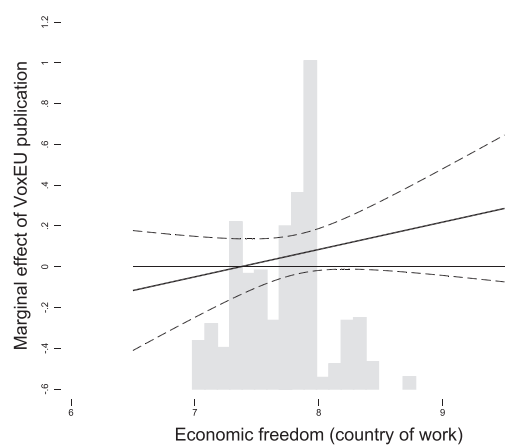

(b) Country of highest degree

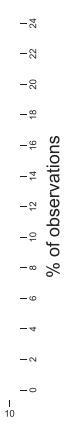

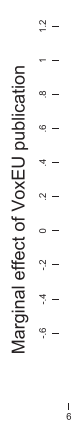

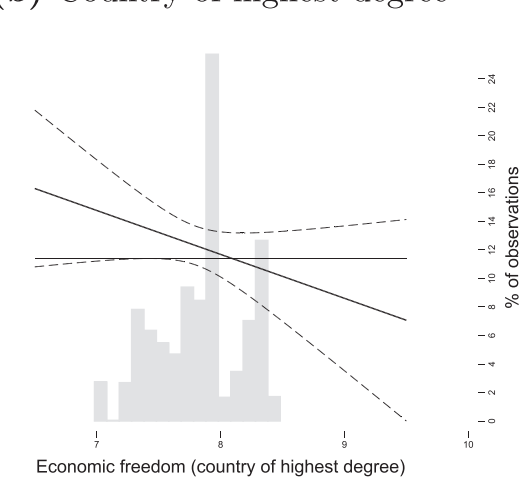

Fig. A3 Marginal effects plots, interaction media involvement with economic freedom. The graphs show the marginal effects of the VoxEU variable on the multiplier estimates. The regressions include country fixed effects and correspond to specifications (6) and (8) of Table 5, respectively. 
Table A1

Summary statistics

\begin{tabular}{|c|c|c|c|c|c|c|}
\hline Variable & Variable definition & Obs & Mean & Std.Dev. & Min & Max \\
\hline Fiscal multiplier estimate & Fiscal multiplier estimate & 2250 & 0.829 & 0.696 & -1.700 & 3.400 \\
\hline Expenditure/GDP (workplace) & Government expenditure to GDP Ratio (country of workplace) & 2250 & 0.429 & 0.056 & 0.216 & 0.653 \\
\hline Expenditure/GDP (education) & Gov. expenditure to GDP ratio (country of highest degree) & 2044 & 0.417 & 0.055 & 0.327 & 0.653 \\
\hline Economic freedom (workplace) & Fraser index of economic freedom (country of workplace) & 2250 & 7.722 & 0.344 & 6.982 & 8.690 \\
\hline Economic freedom (education) & Fraser index of economic freedom (country of highest degree) & 2044 & 7.835 & 0.343 & 6.982 & 8.443 \\
\hline Economic freedom (year of birth) & Fraser index of economic freedom (country and year of birth) & 974 & 5.925 & 0.824 & 3.089 & 7.191 \\
\hline $\begin{array}{l}\text { Economic freedom (year of } \\
\text { publication) }\end{array}$ & Fraser index of economic freedom (country of birth, year of publication) & 1410 & 7.369 & 0.504 & 5.597 & 8.414 \\
\hline Dummy: market orientation (survey) & Dummy whether intensity score above its median value & 794 & 0.496 & 0.500 & 0 & 1 \\
\hline $\begin{array}{l}\text { Dummy: market orientation (survey } \\
\text { \& other sources) }\end{array}$ & $\begin{array}{l}\text { Dummy for market orientation measured with survey answers, open } \\
\text { letters and campaign contributions }\end{array}$ & 905 & 0.470 & 0.499 & 0 & 1 \\
\hline CONS & Public consumption & 2250 & 0.177 & 0.382 & 0 & 1 \\
\hline SPEND & Unspecified public spending & 2250 & 0.381 & 0.486 & 0 & 1 \\
\hline INVEST & Public investment & 2250 & 0.0987 & 0.298 & 0 & 1 \\
\hline MILIT & Public military spending & 2250 & 0.0227 & 0.149 & 0 & 1 \\
\hline TAX & Tax reliefs to private sector & 2250 & 0.225 & 0.418 & 0 & 1 \\
\hline TRANS & Transfers to households & 2250 & 0.0502 & 0.218 & 0 & 1 \\
\hline EMPLOY & Direct public employment & 2250 & 0.0222 & 0.147 & 0 & 1 \\
\hline DEF & Unspecified tax relief or spending increase & 2250 & 0.0227 & 0.149 & 0 & 1 \\
\hline group: EU/EMU/OECD & Multiplier estimated for a group of EU, EMU, and OECD countries & 2250 & 0.071 & 0.257 & 0 & 1 \\
\hline group: EU/EMU & Multiplier estimated for a group of EU and EMU countries & 2250 & 0.138 & 0.345 & 0 & 1 \\
\hline group: Ind. \& Dev. & Multiplier estimated for a group of industrial and developing countries & 2250 & 0.011 & 0.105 & 0 & 1 \\
\hline group: Dev. & Multiplier estimated for a group of developing countries & 2250 & 0.015 & 0.120 & 0 & 1 \\
\hline single: Ind. (low exp/GDP) & $\begin{array}{l}\text { Multiplier estimated for a single industrial country (low } \\
\text { expenditure/GDP) }\end{array}$ & 2250 & 0.507 & 0.500 & 0 & 1 \\
\hline single: Ind. (high exp/GDP) & $\begin{array}{l}\text { Multiplier estimated for a single industrial country (high } \\
\text { expenditure/GDP) }\end{array}$ & 2250 & 0.214 & 0.410 & 0 & 1 \\
\hline Subnational governm. & Multiplier estimated for a group of subnational gov. entities & 2250 & 0.014 & 0.118 & 0 & 1 \\
\hline Theoretical/NA & Multiplier estimated from a purely theoretical model & 2250 & 0.029 & 0.169 & 0 & 1 \\
\hline VAR & Vector Autoregression Model & 2250 & 0.406 & 0.491 & 0 & 1 \\
\hline $\mathrm{RBC}$ & Real Business Cycle Model & 2250 & 0.052 & 0.222 & 0 & 1 \\
\hline NK DSGE & New Keynesian DSGE Model & 2250 & 0.358 & 0.480 & 0 & 1 \\
\hline MACRO & Macro Model & 2250 & 0.088 & 0.283 & 0 & 1 \\
\hline SEE Model & Single Equation Estimation Model & 2250 & 0.096 & 0.294 & 0 & 1 \\
\hline PEAK & Peak Multiplier & 2250 & 0.302 & 0.459 & 0 & 1 \\
\hline HORIZON & Horizon of measurement & 2250 & 1.687 & 0.991 & 0 & 3.871 \\
\hline HORIZON $^{2}$ & Horizon of measurement squared & 2250 & 3.827 & 3.407 & 0 & 14.99 \\
\hline PEAK $\times$ HOR & Peak multiplier $\times$ Horizon & 2250 & 0.330 & 0.715 & 0 & 3.178 \\
\hline $\mathrm{PEAK} \times \mathrm{HOR}^{2}$ & Peak multiplier $\times$ Horizon squared & 2250 & 0.620 & 1.584 & 0 & 10.10 \\
\hline $\mathrm{M} / \mathrm{GDP}($ in $\%)$ & Average Import-to-GDP ratio & 2250 & 20.84 & 11.34 & 6 & 63 \\
\hline Project grant & Study received at least one project grant & 2250 & 0.185 & 0.388 & 0 & 1 \\
\hline National science funding agency & Study received a grant from a nat. science funding agency & 2250 & 0.093 & 0.291 & 0 & 1 \\
\hline Government/ministry & Study received a grant from a government/ministry & 2250 & 0.057 & 0.232 & 0 & 1 \\
\hline European Commission & Study received a grant from the European Commission & 2250 & 0.036 & 0.185 & 0 & 1 \\
\hline National central bank & Study received a grant from a national central bank & 2250 & 0.040 & 0.196 & 0 & 1 \\
\hline (Research) foundation/institute & Study received a grant from a research foundation/institute & 2250 & 0.037 & 0.190 & 0 & 1 \\
\hline University & Working at a university & 2250 & 0.554 & 0.497 & 0 & 1 \\
\hline Government institution & Working at a public institution & 2250 & 0.074 & 0.261 & 0 & 1 \\
\hline Private institution & Working at a private institution & 2250 & 0.021 & 0.145 & 0 & 1 \\
\hline International organization & Working at an international organization & 2250 & 0.156 & 0.363 & 0 & 1 \\
\hline Central bank & Working at a central bank & 2250 & 0.214 & 0.410 & 0 & 1 \\
\hline Journal publication & Refereed journal article & 2250 & 0.420 & 0.494 & 0 & 1 \\
\hline Tenure position & Researcher has a tenure position & 1246 & 0.660 & 0.474 & 0 & 1 \\
\hline Full professorship & Researcher is a full professor & 1246 & 0.521 & 0.500 & 0 & 1 \\
\hline Publication on VoxEU & Author has published on VoxEU.com & 2250 & 0.458 & 0.498 & 0 & 1 \\
\hline Multiple authors & Study written by multiple authors from different countries & 2250 & 0.859 & 0.348 & 0 & 1 \\
\hline $\begin{array}{l}\text { Multiple authors from diff. countries } \\
\text { (workplace) }\end{array}$ & Study by multiple authors from different countries (workplace) & 2250 & 0.335 & 0.472 & 0 & 1 \\
\hline $\begin{array}{l}\text { Multiple authors from diff. countries } \\
\text { (education) }\end{array}$ & $\begin{array}{l}\text { Multiple authors who received their highest degree in different } \\
\text { countries }\end{array}$ & 2250 & 0.469 & 0.499 & 0 & 1 \\
\hline $\begin{array}{l}\text { Coauthors not from governm. } \\
\text { institution }\end{array}$ & $\begin{array}{l}\text { At least one author working at a government institution and one } \\
\text { elsewhere }\end{array}$ & 2250 & 0.024 & 0.154 & 0 & 1 \\
\hline
\end{tabular}


Table A2

National imprint \& individual market orientation - all covariate estimates.

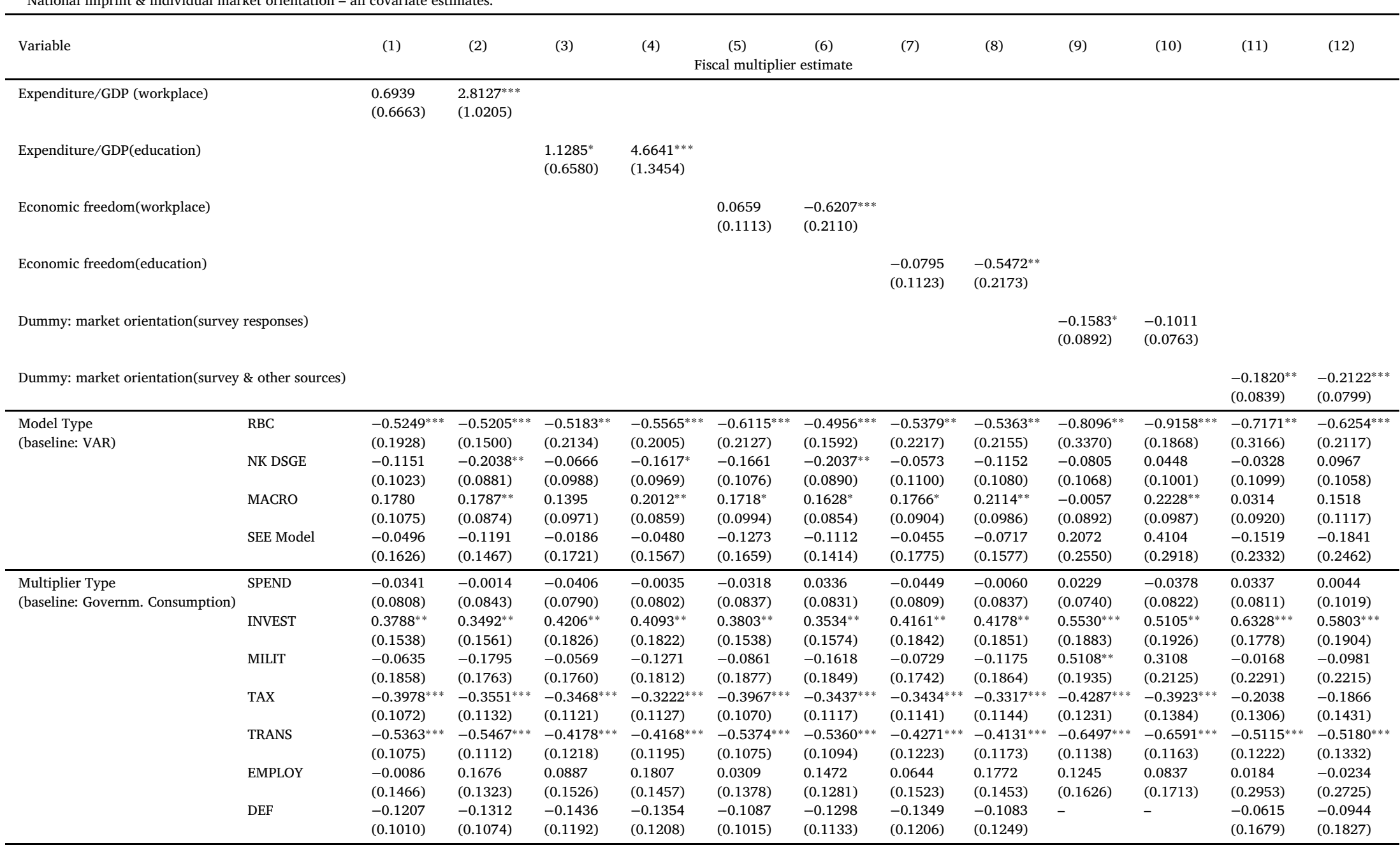

Economic freedom(workplace)

$\begin{array}{ll}1.1285^{*} & 4.6641^{* * *} \\ (0.6580) & (1.3454)\end{array}$

$0.0659-0.6207^{* * *}$

$-0.0795-0.5472^{* *}$

$-0.1583^{*} \quad-0.1011$

Dummy: market orientation(survey \& other sources)

(continued on next page) 
Table A2 (continued)

\begin{tabular}{|c|c|c|c|c|c|c|c|c|c|c|c|c|c|}
\hline \multirow[t]{2}{*}{ Variable } & & (1) & (2) & (3) & (4) & (5) & (6) & (7) & (8) & (9) & (10) & (11) & (12) \\
\hline & \multicolumn{13}{|c|}{ Fiscal multiplier estimate } \\
\hline \multirow{11}{*}{$\begin{array}{l}\text { Country Coverage } \\
\text { (baseline: group: EU/EMU/OECD) }\end{array}$} & group: EU/EMU & $\begin{array}{l}0.5346^{* * *} \\
(0.1710)\end{array}$ & $\begin{array}{l}0.4839^{* * *} \\
(0.1744)\end{array}$ & $\begin{array}{l}0.5145^{* * *} \\
(0.1898)\end{array}$ & $\begin{array}{l}0.4585^{* *} \\
(0.1768)\end{array}$ & $\begin{array}{l}0.5608^{* * *} \\
(0.1716)\end{array}$ & $\begin{array}{l}0.5387^{* * *} \\
(0.1786)\end{array}$ & $\begin{array}{l}0.5498^{* * *} \\
(0.1937)\end{array}$ & $\begin{array}{l}0.5180^{* *} \\
(0.2050)\end{array}$ & $\begin{array}{l}0.4363^{* *} \\
(0.1721)\end{array}$ & $\begin{array}{l}0.0222 \\
(0.1423)\end{array}$ & $\begin{array}{l}0.5657^{* * *} \\
(0.1994)\end{array}$ & $\begin{array}{l}0.3687 \\
(0.2235)\end{array}$ \\
\hline & group: Ind. \& & $0.6463^{*}$ & $0.5743^{*}$ & $0.9964^{* * *}$ & $0.9495^{* * *}$ & $0.6787^{*}$ & $0.7387^{* *}$ & $1.0878^{* * *}$ & $1.1461^{* * *}$ & 0.4673 & $0.3866^{*}$ & $1.1081^{* * *}$ & $1.2847^{* * *}$ \\
\hline & Dev. & $(0.3403)$ & $(0.3011)$ & $(0.3544)$ & $(0.2609)$ & $(0.3560)$ & $(0.3053)$ & $(0.3369)$ & $(0.2474)$ & $(0.3199)$ & $(0.1950)$ & $(0.2859)$ & $(0.2630)$ \\
\hline & group: Dev. & 0.0862 & 0.1020 & 0.1210 & 0.1276 & 0.0703 & 0.1094 & 0.1137 & 0.1316 & -0.1775 & $-0.1514^{*}$ & 0.0155 & 0.0614 \\
\hline & & $(0.1381)$ & $(0.1424)$ & $(0.1465)$ & $(0.1552)$ & $(0.1382)$ & $(0.1499)$ & $(0.1462)$ & $(0.1659)$ & $(0.1248)$ & $(0.0897)$ & $(0.1671)$ & $(0.1601)$ \\
\hline & single: Ind. & $0.4468^{* *}$ & $0.5428^{* * *}$ & $0.4225^{* *}$ & $0.4743^{* * *}$ & $0.4509^{* * *}$ & $0.5902^{* * *}$ & $0.4346^{* *}$ & $0.4961^{* * *}$ & 0.2399 & 0.0786 & $0.3794^{* *}$ & $0.3854^{* *}$ \\
\hline & (low exp/GDP) & $(0.1707)$ & $(0.1675)$ & $(0.1746)$ & $(0.1800)$ & $(0.1709)$ & $(0.1716)$ & $(0.1745)$ & $(0.1877)$ & $(0.1609)$ & $(0.1184)$ & $(0.1841)$ & $(0.1929)$ \\
\hline & single: Ind. & $0.3942^{* * *}$ & $0.5772^{* * *}$ & $0.3891^{* *}$ & $0.4771^{* * *}$ & $0.4263^{* * *}$ & $0.6285^{* * *}$ & $0.4018^{* *}$ & $0.5047^{* * *}$ & 0.2825 & 0.1798 & $0.3242^{*}$ & $0.3822^{*}$ \\
\hline & (high exp/GDP) & $(0.1500)$ & $(0.1594)$ & $(0.1558)$ & $(0.1681)$ & $(0.1529)$ & $(0.1653)$ & $(0.1531)$ & $(0.1810)$ & $(0.1702)$ & $(0.1160)$ & $(0.1933)$ & $(0.1999)$ \\
\hline & Subnational gov. & $\begin{array}{l}0.6972 \\
(0.6220)\end{array}$ & $\begin{array}{l}0.8287 \\
(0.6244)\end{array}$ & $\begin{array}{l}0.6801 \\
(0.6182)\end{array}$ & $\begin{array}{l}0.6500 \\
(0.6139)\end{array}$ & $\begin{array}{l}0.7514 \\
(0.6174)\end{array}$ & $\begin{array}{l}0.8365 \\
(0.5965)\end{array}$ & $\begin{array}{l}0.7006 \\
(0.6100)\end{array}$ & $\begin{array}{l}0.6957 \\
(0.5727)\end{array}$ & $\begin{array}{l}-0.4203 \\
(0.3816)\end{array}$ & $\begin{array}{l}-0.8185^{* *} \\
(0.3199)\end{array}$ & $\begin{array}{l}0.0465 \\
(0.3345)\end{array}$ & $\begin{array}{l}0.1477 \\
(0.3843)\end{array}$ \\
\hline & Theoretical/NA & $\begin{array}{l}0.0021 \\
(0.1461)\end{array}$ & $\begin{array}{l}-0.0350 \\
(0.1382)\end{array}$ & $\begin{array}{l}0.0095 \\
(0.1559)\end{array}$ & $\begin{array}{l}0.0075 \\
(0.1478)\end{array}$ & $\begin{array}{l}-0.0326 \\
(0.1493)\end{array}$ & $\begin{array}{l}-0.0544 \\
(0.1449)\end{array}$ & $\begin{array}{l}-0.0005 \\
(0.1583)\end{array}$ & $\begin{array}{l}-0.0613 \\
(0.1643)\end{array}$ & $\begin{array}{l}-0.2584 \\
(0.1580)\end{array}$ & $\begin{array}{l}-0.1788^{*} \\
(0.0914)\end{array}$ & $\begin{array}{l}-0.0634 \\
(0.1698)\end{array}$ & $\begin{array}{l}0.0087 \\
(0.1486)\end{array}$ \\
\hline \multirow{6}{*}{$\begin{array}{l}\text { Control Variables } \\
\text { (baseline: cumulative multiplier) }\end{array}$} & PEAK & $\begin{array}{l}0.1933 \\
(0.1403)\end{array}$ & $\begin{array}{l}0.2988^{* *} \\
(0.1357)\end{array}$ & $\begin{array}{l}0.1554 \\
(0.1389)\end{array}$ & $\begin{array}{l}0.1757 \\
(0.1342)\end{array}$ & $\begin{array}{l}0.1907 \\
(0.1368)\end{array}$ & $\begin{array}{l}0.3164^{* *} \\
(0.1321)\end{array}$ & $\begin{array}{l}0.1318 \\
(0.1379)\end{array}$ & $\begin{array}{l}0.1516 \\
(0.1333)\end{array}$ & $\begin{array}{l}0.0218 \\
(0.1306)\end{array}$ & $\begin{array}{l}0.0058 \\
(0.1007)\end{array}$ & $\begin{array}{l}0.1751 \\
(0.1293)\end{array}$ & $\begin{array}{l}0.1904^{*} \\
(0.1071)\end{array}$ \\
\hline & HORIZON & $\begin{array}{l}-0.0668 \\
(0.1538)\end{array}$ & $\begin{array}{l}0.0196 \\
(0.1337)\end{array}$ & $\begin{array}{l}-0.1951 \\
(0.1321)\end{array}$ & $\begin{array}{l}-0.1795 \\
(0.1281)\end{array}$ & $\begin{array}{l}-0.0482 \\
(0.1536)\end{array}$ & $\begin{array}{l}0.0058 \\
(0.1313)\end{array}$ & $\begin{array}{l}-0.2029 \\
(0.1396)\end{array}$ & $\begin{array}{l}-0.1928 \\
(0.1325)\end{array}$ & $\begin{array}{l}-0.1078 \\
(0.1036)\end{array}$ & $\begin{array}{l}-0.0630 \\
(0.1014)\end{array}$ & $\begin{array}{l}-0.0869 \\
(0.1016)\end{array}$ & $\begin{array}{l}-0.0064 \\
(0.1109)\end{array}$ \\
\hline & HORIZON $^{2}$ & $\begin{array}{l}0.0488 \\
(0.0396)\end{array}$ & $\begin{array}{l}0.0291 \\
(0.0335)\end{array}$ & $\begin{array}{l}0.0864^{* *} \\
(0.0345)\end{array}$ & $\begin{array}{l}0.0817^{* *} \\
(0.0339)\end{array}$ & $\begin{array}{l}0.0417 \\
(0.0397)\end{array}$ & $\begin{array}{l}0.0347 \\
(0.0332)\end{array}$ & $\begin{array}{l}0.0867^{* *} \\
(0.0366)\end{array}$ & $\begin{array}{l}0.0831^{* *} \\
(0.0356)\end{array}$ & $\begin{array}{l}0.0555^{*} \\
(0.0308)\end{array}$ & $\begin{array}{l}0.0489^{*} \\
(0.0291)\end{array}$ & $\begin{array}{l}0.0544^{*} \\
(0.0283)\end{array}$ & $\begin{array}{l}0.0366 \\
(0.0317)\end{array}$ \\
\hline & PEAK $\times$ HOR & $\begin{array}{l}-0.0725 \\
(0.2149)\end{array}$ & $\begin{array}{l}-0.1840 \\
(0.1821)\end{array}$ & $\begin{array}{l}0.0501 \\
(0.2068)\end{array}$ & $\begin{array}{l}0.0576 \\
(0.1932)\end{array}$ & $\begin{array}{l}-0.1239 \\
(0.2200)\end{array}$ & $\begin{array}{l}-0.1591 \\
(0.1861)\end{array}$ & $\begin{array}{l}0.0443 \\
(0.2165)\end{array}$ & $\begin{array}{l}0.0432 \\
(0.2062)\end{array}$ & $\begin{array}{l}0.0874 \\
(0.2011)\end{array}$ & $\begin{array}{l}0.0732 \\
(0.1643)\end{array}$ & $\begin{array}{l}-0.0010 \\
(0.1939)\end{array}$ & $\begin{array}{l}-0.0406 \\
(0.1972)\end{array}$ \\
\hline & $\mathrm{PEAK} \times \mathrm{HOR}^{2}$ & $\begin{array}{l}0.0546 \\
(0.0633)\end{array}$ & $\begin{array}{l}0.0827 \\
(0.0546)\end{array}$ & $\begin{array}{l}0.0181 \\
(0.0634)\end{array}$ & $\begin{array}{l}0.0129 \\
(0.0599)\end{array}$ & $\begin{array}{l}0.0721 \\
(0.0647)\end{array}$ & $\begin{array}{l}0.0705 \\
(0.0569)\end{array}$ & $\begin{array}{l}0.0237 \\
(0.0653)\end{array}$ & $\begin{array}{l}0.0201 \\
(0.0638)\end{array}$ & $\begin{array}{l}0.0053 \\
(0.0688)\end{array}$ & $\begin{array}{l}0.0195 \\
(0.0603)\end{array}$ & $\begin{array}{l}0.0276 \\
(0.0603)\end{array}$ & $\begin{array}{l}0.0433 \\
(0.0627)\end{array}$ \\
\hline & $\begin{array}{l}\text { M/GDP (in \%) } \\
\text { (country sample) }\end{array}$ & $\begin{array}{l}-0.0106^{* * *} \\
(0.0036)\end{array}$ & $\begin{array}{l}-0.0098^{* * *} \\
(0.0033)\end{array}$ & $\begin{array}{l}-0.0111^{* * *} \\
(0.0035)\end{array}$ & $\begin{array}{l}-0.0126^{* * *} \\
(0.0036)\end{array}$ & $\begin{array}{l}-0.0102^{* * *} \\
(0.0036)\end{array}$ & $\begin{array}{l}-0.0100^{* * *} \\
(0.0032)\end{array}$ & $\begin{array}{l}-0.0111^{* * *} \\
(0.0036)\end{array}$ & $\begin{array}{l}-0.0122^{* * *} \\
(0.0037)\end{array}$ & $\begin{array}{l}-0.0117^{* * *} \\
(0.0027)\end{array}$ & $\begin{array}{l}-0.0089^{* * *} \\
(0.0020)\end{array}$ & $\begin{array}{l}-0.0103^{* * *} \\
(0.0022)\end{array}$ & $\begin{array}{l}-0.0081^{* * *} \\
(0.0024)\end{array}$ \\
\hline \multicolumn{2}{|l|}{ Constant } & $\begin{array}{l}0.3513 \\
(0.4023)\end{array}$ & $\begin{array}{l}-0.9314 \\
(0.6158)\end{array}$ & $\begin{array}{l}0.2252 \\
(0.3325)\end{array}$ & $\begin{array}{l}-1.7794^{* *} \\
(0.7415)\end{array}$ & $\begin{array}{l}0.1498 \\
(0.8827)\end{array}$ & $\begin{array}{l}5.0804^{* * *} \\
(1.5367)\end{array}$ & $\begin{array}{l}1.3216 \\
(0.9543)\end{array}$ & $\begin{array}{l}4.7000^{* * *} \\
(1.6219)\end{array}$ & $\begin{array}{l}0.9649^{* * *} \\
(0.1640)\end{array}$ & $\begin{array}{l}0.8979^{* * *} \\
(0.0996)\end{array}$ & $\begin{array}{l}0.6943^{* * *} \\
(0.1904)\end{array}$ & $\begin{array}{l}0.5753^{* * *} \\
(0.1918)\end{array}$ \\
\hline \multicolumn{2}{|l|}{ Country fixed effects } & & $x$ & & $x$ & & $x$ & & $x$ & & $\times$ & & $\times$ \\
\hline \multicolumn{2}{|l|}{ Observations } & 2250 & 2250 & 2044 & 2044 & 2250 & 2250 & 2044 & 2044 & 794 & 794 & 905 & 905 \\
\hline \multicolumn{2}{|l|}{ R-squared } & 0.2692 & 0.3348 & 0.2731 & 0.3046 & 0.2677 & 0.3409 & 0.2677 & 0.2935 & 0.3386 & 0.4336 & 0.3512 & 0.4211 \\
\hline
\end{tabular}

Notes: ${ }^{* * *} \mathrm{p}<0.01,{ }^{* *} \mathrm{p}<0.05,{ }^{*} \mathrm{p}<0.1$. Standard errors are clustered by study. The expenditure-to-GDP ratio (columns 1-4) and the Fraser economic freedom index (columns 5-8) correspond to the year of publication. 
Table A3

National imprint \& individual market orientation - alternative WLS estimation

\begin{tabular}{|c|c|c|c|c|c|c|}
\hline \multirow[t]{2}{*}{ Variable } & (1) & $(2)$ & (3) & (4) & (5) & (6) \\
\hline & \multicolumn{6}{|c|}{ Fiscal multiplier estimate } \\
\hline Expenditure/GDP (workplace) & $\begin{array}{l}2.2324 \\
(1.3729)\end{array}$ & & & & & \\
\hline Expenditure/GDP (education) & & $\begin{array}{l}3.5407^{* *} \\
(1.4050)\end{array}$ & & & & \\
\hline Economic freedom (workplace) & & & $\begin{array}{l}-0.4910^{*} \\
(0.2582)\end{array}$ & & & \\
\hline Economic freedom (education) & & & & $\begin{array}{l}-0.6138^{* *} \\
(0.2455)\end{array}$ & & \\
\hline Dummy: market orientation (survey responses) & & & & & $\begin{array}{l}-0.0420 \\
(0.1109)\end{array}$ & \\
\hline Dummy: market orientation (survey \& other sources) & & & & & & $\begin{array}{l}-0.3077^{* * *} \\
(0.0947)\end{array}$ \\
\hline Multiplier type controls & $\times$ & $x$ & $\times$ & $\times$ & $\times$ & $\times$ \\
\hline Other controls & $\times$ & $x$ & $\times$ & $x$ & $\times$ & $\times$ \\
\hline Model controls & $\times$ & $x$ & $\times$ & $x$ & $\times$ & $\times$ \\
\hline Country coverage & $\times$ & $x$ & $\times$ & $\times$ & $\times$ & $\times$ \\
\hline Country fixed effects & $\times$ & $\times$ & $\times$ & $\times$ & $\times$ & $\times$ \\
\hline Observations & 2250 & 2044 & 2250 & 2044 & 794 & 905 \\
\hline R-squared & 0.3031 & 0.2660 & 0.3097 & 0.2699 & 0.3944 & 0.3708 \\
\hline
\end{tabular}

Notes: ${ }^{* *} \mathrm{p}<0.01,{ }^{* *} \mathrm{p}<0.05,{ }^{*} \mathrm{p}<0.1$. Standard errors are clustered by study. The expenditure-to-GDP ratio (columns 1-2) and the Fraser economic freedom index (columns 3-4) correspond to the year of publication.

Table A4

National imprint \& individual market orientation - excluding observations with the US as a work/education country

\begin{tabular}{|c|c|c|c|c|c|}
\hline \multirow[t]{2}{*}{ Variable } & (1) & (2) & (3) & (4) & (5) \\
\hline & \multicolumn{5}{|c|}{ Fiscal multiplier estimate } \\
\hline Expenditure/GDP (workplace) & $\begin{array}{l}1.4468 \\
(1.2976)\end{array}$ & & & & \\
\hline Expenditure/GDP (education) & & $\begin{array}{l}2.8569^{* * *} \\
(1.4256)\end{array}$ & & & \\
\hline Economic freedom (workplace) & & & $\begin{array}{l}-0.7364^{*} \\
(0.3727)\end{array}$ & & \\
\hline Economic freedom (education) & & & & $\begin{array}{l}-0.1388 \\
(0.2636)\end{array}$ & \\
\hline Dummy: market orientation (survey \& other sources) & & & & & $\begin{array}{l}-0.0880 \\
(0.0923)\end{array}$ \\
\hline Multiplier type controls & $x$ & $\times$ & $\times$ & $x$ & $\times$ \\
\hline Other controls & $x$ & $\times$ & $\times$ & $\times$ & $x$ \\
\hline Model controls & $x$ & $x$ & $\times$ & $\times$ & $x$ \\
\hline Country coverage & $x$ & $\times$ & $\times$ & $x$ & $x$ \\
\hline Country fixed effects & $\times$ & $\times$ & $\times$ & $\times$ & $\times$ \\
\hline Observations & 1395 & 1099 & 1395 & 1099 & 636 \\
\hline R-squared & 0.3691 & 0.3502 & 0.3761 & 0.3435 & 0.5084 \\
\hline
\end{tabular}

Notes: ${ }^{* * *} \mathrm{p}<0.01,{ }^{* *} \mathrm{p}<0.05,{ }^{*} \mathrm{p}<0.1$. Standard errors are clustered by study. The expenditure-to-GDP ratio (columns 1-2) and the Fraser economic freedom index (columns 3-4) correspond to the year of publication. 
Table A5

Coding of project grants into categories

\begin{tabular}{|c|c|c|c|c|}
\hline National science funding agency & European Commission & Government & Central Bank & (Research) Foundation/Institute \\
\hline National Science Foundation & $\begin{array}{l}\text { European } \\
\text { Commission }\end{array}$ & $\begin{array}{l}\text { Pierre Werner Chair Programme } \\
\text { on Monetary Union }\end{array}$ & Banco D'Espania & $\begin{array}{l}\text { Stanford Center for Economic } \\
\text { Policy }\end{array}$ \\
\hline \multirow{7}{*}{$\begin{array}{l}\text { Social Sciences and Humanities } \\
\text { Research Council of Canada } \\
\text { German Research Foundation } \\
\text { Irish Research Council for the } \\
\text { Humanities and Social Sciences }\end{array}$} & & World Bank (Knowledge for & Fondation Banque & Barcelona GSE Research Network \\
\hline & & World Program) & de France & (CREA) \\
\hline & & Arbeitskammer Wien & & Sloan Foundation \\
\hline & & Spanish Ministry of Education & & Centre for Macroeconomics (CfM) \\
\hline & & and Science & & \\
\hline & & Spanish Ministry of Science and & & Institute for New Economic \\
\hline & & Technology & & Thinking (INET) \\
\hline
\end{tabular}

Table A6

Coding of workplaces into categories

\begin{tabular}{|c|c|c|c|}
\hline Government institution & Private institution & International organization & Central Bank \\
\hline Belgian Federal Planning Bureau & Goldman Sachs & IMF & $\begin{array}{l}\text { National central banks (ITA, ESP, } \\
\text { DEU, BEL) }\end{array}$ \\
\hline $\begin{array}{l}\text { Economic Bureau of Spanish Prime } \\
\text { Minister }\end{array}$ & Hans-Böckler Foundation & OECD & ECB \\
\hline $\begin{array}{l}\text { European Commission } \\
\text { French Ministry of the Economy and } \\
\text { Finance } \\
\text { INSEE France } \\
\text { Office of the (US) Vice President Elect }\end{array}$ & Moody's Analytics & World Bank & $\begin{array}{l}\text { Federal Reserve System } \\
\text { Federal Bank of Chicago, Kansas City, } \\
\text { Minneapolis, New York, Chicago }\end{array}$ \\
\hline
\end{tabular}

Table A7

Interaction co-authorship with national imprint, multiple authors

\begin{tabular}{|c|c|c|c|c|c|c|c|c|}
\hline \multirow[t]{2}{*}{ Variable } & (1) & (2) & (3) & (4) & (5) & (6) & (7) & $(8)$ \\
\hline & \multicolumn{8}{|c|}{ Fiscal multiplier estimate } \\
\hline Expenditure/GDP (workplace) & $\begin{array}{l}0.7818 \\
(0.9789)\end{array}$ & $\begin{array}{l}3.3666^{* *} \\
(1.3391)\end{array}$ & & & & & & \\
\hline Expenditure/GDP (education) & & & $\begin{array}{l}3.0650 * * \\
(1.4585)\end{array}$ & $\begin{array}{l}6.3738^{* * *} \\
(1.7367)\end{array}$ & & & & \\
\hline Exp/GDP $\times$ mult. authors & $\begin{array}{l}-0.1074 \\
(1.2693)\end{array}$ & $\begin{array}{l}-0.3336 \\
(1.1355)\end{array}$ & $\begin{array}{l}-2.6202^{*} \\
(1.5013)\end{array}$ & $\begin{array}{l}-2.4609 \\
(1.5543)\end{array}$ & & & & \\
\hline Fraser index (workplace) & & & & & $\begin{array}{l}0.0496 \\
(0.2605)\end{array}$ & $\begin{array}{l}-0.6543^{* *} \\
(0.2651)\end{array}$ & & \\
\hline Fraser index (education) & & & & & & & $\begin{array}{l}-0.4641 \\
(0.2895)\end{array}$ & $\begin{array}{l}-0.8280^{* *} \\
(0.3152)\end{array}$ \\
\hline Fraser index $\times$ mult. authors & & & & & $\begin{array}{l}0.0204 \\
(0.2758)\end{array}$ & $\begin{array}{l}0.0374 \\
(0.2194)\end{array}$ & $\begin{array}{l}0.5044^{*} \\
(0.3020)\end{array}$ & $\begin{array}{l}0.4232 \\
(0.2971)\end{array}$ \\
\hline Multiple authors & $\begin{array}{l}0.0675 \\
(0.5520)\end{array}$ & $\begin{array}{l}0.2043 \\
(0.4809)\end{array}$ & $\begin{array}{l}1.1202^{*} \\
(0.6223)\end{array}$ & $\begin{array}{l}1.0672^{*} \\
(0.6277)\end{array}$ & $\begin{array}{l}-0.1448 \\
(2.1529)\end{array}$ & $\begin{array}{l}-0.2681 \\
(1.7029)\end{array}$ & $\begin{array}{l}-3.9124 \\
(2.3947)\end{array}$ & $\begin{array}{l}-3.2801 \\
(2.3584)\end{array}$ \\
\hline Multiplier type controls & $\times$ & $\times$ & $x$ & $\times$ & $\times$ & $\times$ & $\times$ & $\times$ \\
\hline Other controls & $\times$ & $x$ & $x$ & $x$ & $\times$ & $\times$ & $x$ & $x$ \\
\hline Model controls & $\times$ & $x$ & $x$ & $x$ & $\times$ & $\times$ & $x$ & $\times$ \\
\hline Country coverage & $x$ & $x$ & $x$ & $x$ & $x$ & $x$ & $x$ & $x$ \\
\hline Country fixed effects & & $\times$ & & $\times$ & & $\times$ & & $\times$ \\
\hline Observations & 2250 & 2250 & 2044 & 2044 & 2250 & 2250 & 2044 & 2044 \\
\hline R-squared & 0.2694 & 0.3359 & 0.2810 & 0.3111 & 0.2678 & 0.3411 & 0.2777 & 0.2998 \\
\hline
\end{tabular}

Notes: ${ }^{* *} \mathrm{p}<0.01,{ }^{*} \mathrm{p}<0.05,{ }^{*} \mathrm{p}<0.1$. Standard errors are clustered by study.

\section{Conflict of interests declaration}

We declare that there is no conflict of interests with respect to the topic, contents or results of the submitted study. 


\section{References}

Alesina, A., Tabellini, G., Trebbi, F., 2017. Is Europe an optimal political area? NBER Working Papers, vol. 23325.

Alm, J., Torgler, B., 2006. Culture differences and tax morale in the United States and in Europe. J. Econ. Psychol. 27 (2), 224-246.

Almunia, M., Lopez-Rodriguez, D., 2018. Under the Radar: The Effects of Monitoring Firms on Tax Compliance. American Economic Journal: Economic Policy, 10 (1), 1-38. https://www.aeaweb.org/articles?id=10.1257/pol.20160229.

Anderson, R.G., Kichkha, A., 2017. Replication, meta-analysis, and research synthesis in economics. Am. Econ. Rev. 107 (5), 56-59.

Angelopoulos, K., Economides, G., Kammas, P., 2012. Does cabinet ideology matter for the structure of tax policies? Eur. J. Polit. Econ. 28 (4), 620-635.

Avis, E., Ferraz, C., Finan, F., 2016. Do Government Audits Reduce Corruption? Estimating the Impacts of Exposing Corrupt Politicians. NBER Working Paper No. 22443.

Baker, C.B., Johnsrud, M.T., Crismon, M.L., Rosenheck, R.A., Woods, S.W., 2003. Quantitative analysis of sponsorship bias in economic studies of antidepressants. Br. J. Psychiatr. 183 (6), 498-506.

Baskaran, T., 2011. Fiscal decentralization, ideology, and the size of the public sector. Eur. J. Polit. Econ. 27 (3), $485-506$.

Batini, N., Eyraud, L., Forni, L., Weber, A., 2014. Fiscal multipliers: size, determinants, and use in macroeconomic projections. IMF Technical Notes and Manuals, vol. 14/04.

Battiston, P., Duncan, D., Gamba, S., Santoro, A., 2020. Audit publicity and tax compliance: a natural experiment. Scand. J. Econ. 122 (1), 81-108.

Bekelman, J., Li, Y., Gross, C., 2003. Scope and impact of financial conflicts of interest in biomedical research: a systematic review. J. Am. Med. Assoc. 289 (4), 454-465.

Bell, C.M., Urbach, D.R., Ray, J.G., Bayoumi, A., Rosen, A.B., Greenberg, D., Neumann, P.J., 2006. Bias in published cost effectiveness studies: systematic review. BMJ 332 (7543), 699-703.

Blendon, R.J., Benson, J.M., Brodie, M., Morin, R., Altman, D.E., Gitterman, D., Brossard, M., James, M., 1997. Bridging the gap between the public's and economists' views of the economy. J. Econ. Perspect. 11 (3), 105-118.

Bobonis, G.J., Cámara Fuertes, L.R., Schwabe, R., 2016. Monitoring corruptible politicians. Am. Econ. Rev. 106 (8), $2371-2405$.

Brunnermeier, M.K., James, H., Landau, J.-P., 2016. The Euro and the Battle of Ideas. Princeton University Press.

Camerer, C.F., Dreber, A., Forsell, E., Ho, T.-H., Huber, J., Johannesson, M., Kirchler, M., Almenberg, J., Altmejd, A., Chan, T., et al., 2016. Evaluating replicability of laboratory experiments in economics. Science 351 (6280), 1433-1436.

Caplan, B., 2002. Systematically biased beliefs about economics: robust evidence of judgemental anomalies from the survey of Americans and economists on the economy. Econ. J. 112 (479), 433-458.

Christiano, L., Eichenbaum, M., Rebelo, S., 2011. When is the government spending multiplier large? J. Polit. Econ. 119 (1), $78-121$.

Cusack, T.R., 1997. Partisan politics and public finance: changes in public spending in the industrialized democracies, 1955-1989. Publ. Choice 91, 375-395.

De Long, J.B., Lang, K., 1992. Are all economic hypotheses false? J. Polit. Econ. 100 (6), 1257-1272.

De Ville, F., Berckvens, D., 2015. What do Eurozone academics think about EMU reform? On broad support and German exceptionalism. Bruges Political Research Papers, vol. 41.

DellaVigna, S., Hermle, J., 2014. Does Conflict of Interest Lead to Biased Coverage? Evidence from Movie Reviews. NBER Working Paper No. 20661.

Dobrescu, L.I., Luca, M., Motta, A., 2013. What makes a critic tick? Connected authors and the determinants of book reviews. J. Econ. Behav. Organ. 96, 85-103.

Doucouliagos, C., Stanley, T.D., 2013. Are all economic facts greatly exaggerated? Theory competition and selectivity. J. Econ. Surv. 27 (2), $316-339$.

Doucouliagos, H., Paldam, M., Stanley, T., 2018. Skating on thin evidence: implications for public policy. Eur. J. Polit. Econ. 54, 16-25.

Doucouliagos, H., Stanley, T.D., 2009. Publication selection bias in minimum-wage research? A meta-regression analysis. Br. J. Ind. Relat 47 (2), $406-428$.

Dyson, K., 1999. The franco-German relationship and economic and monetary union: using europe to 'bind Leviathan'. W. Eur. Polit. 22 (1), 25-44.

Ferraz, C., Finan, F., 2011. Electoral accountability and corruption: evidence from the audits of local governments. Am. Econ. Rev. 101 (4), $1274-1311$.

Frey, B.S., 2003. Publishing as prostitution? - choosing between one's own ideas and academic success. Publ. Choice 116 (1-2), $205-223$.

Friedberg, M., Saffran, B., Stinson, T., Nelson, W., Bennett, C., 1999. Evaluation of conflict of interest in economic analyses of new drugs used in oncology. J. Am. Med. Assoc. 282 (15), 1453-1457.

Gechert, S., 2015. What fiscal policy is most effective? A meta-regression analysis. Oxf. Econ. Pap. 67 (3), $553-580$.

Gelman, A., Carlin, J., 2014. Beyond power calculations: assessing type s (sign) and type m (magnitude) errors. Perspect. Psychol. Sci. 9 (6), 641-651.

Glass, G.V., 1976. Primary, secondary, and meta-analysis of research. Educ. Res. 5 (10), 3-8.

Greene, W.H., 2003. Econometric Analysis. Pearson Education India.

Gründler, K., Potrafke, N., 2019. Ideologically-charged Terminology: Austerity, Fiscal Consolidation, and Sustainable Governance. CESifo Working Paper 7613.

Guiso, L., Herrera, H., Morelli, M., 2016. Cultural differences and institutional integration. J. Int. Econ. 99, $97-113$.

Hedengren, D., Klein, D.B., Milton, C., 2010. Economist petitions: ideology revealed. Econ. J. Watch 7 (3), $288-319$.

Heinemann, F., Moessinger, M.-D., Yeter, M., 2018. Do fiscal rules constrain fiscal policy? A meta-regression-analysis. Eur. J. Polit. Econ. 51, 69-92.

Herwartz, H., Theilen, B., 2014. Partisan influence on social spending under market integration, fiscal pressure and institutional change. Eur. J. Polit. Econ. 34, $409-424$.

Hien, J., 2019. The religious foundations of the European crisis. J. Commun. Media Stud.: J. Common. Mark. Stud. 57 (2), $185-204$.

Ilzetzki, E., Mendoza, E.G., Végh, C.A., 2013. How big (small?) are fiscal multipliers? J. Monetary Econ. 60 (2), $239-254$.

Ioannidis, J.P.A., 2005. Why most published research findings are false. PLoS Med. 2 (8).

Ioannidis, J.P.A., Stanley, T.D., Doucouliagos, H., 2017. The power of bias in economics research. Econ. J. 127 (605), F236-F265.

Jochimsen, B., Thomasius, S., 2014, 06. The perfect finance minister: whom to appoint as finance minister to balance the budget. Eur. J. Polit. Econ. 34, 390-408.

Kirchgässner, G., 2014. On the Process of Scientific Policy Advice - with Special Reference to Economic Policy. CESifo Working Paper Series 5144.

Kleven, H.J., Knudsen, M.B., Kreiner, C.T., Pedersen, S., Saez, E., 2011. Unwilling or unable to cheat? Evidence from a tax audit experiment in Denmark. Econometrica 79 (3), 651-692.

Leamer, E.E., 2010. Tantalus on the road to asymptopia. J. Econ. Perspect. 24 (2), 31-46.

Li, D., 2017. Expertise versus bias in evaluation: evidence from the NIH. Am. Econ. J. Appl. Econ. 9 (2), 60-92.

McShane, B.B., Gal, D., Gelman, A., Robert, C., Tackett, J.L., 2019. Abandon statistical significance. Am. Statistician 73 (Suppl. 1), 235-245.

Mueller-Langer, F., Fecher, B., Harhoff, D., Wagner, G.G., 2019. Replication studies in economics - how many and which papers are chosen for replication, and why? Res. Pol. 48 (1), 62-83.

Necker, S., 2014. Scientific misbehavior in economics. Res. Pol. 43 (10), 1747-1759.

Nelson, J.P., Kennedy, P.E., 2009. The use (and abuse) of meta-analysis in environmental and natural resource economics: an assessment. Environ. Resour. Econ. 42 (3), 345-377.

Niskanen, W., 1971. Representative Government and Bureaucracy. Al-dine/Atherton, Chicago.

Niskanen, W.A., 1975. Bureaucrats and politicians. J. Law Econ. 18 (3), 617-643.

Olken, B.A., 2007. Monitoring corruption: evidence from a field experiment in Indonesia. J. Polit. Econ. 115 (2), $200-249$.

Paldam, M., 2018. A model of the representative economist, as researcher and policy advisor. Eur. J. Polit. Econ. 54 (C), 5-15.

Ramey, V.A., 2011. Can government purchases stimulate the economy? J. Econ. Lit. 49 (3), 673-685.

Ramey, V.A., 2019. Ten years after the financial crisis: what have we learned from the renaissance in fiscal research? J. Econ. Perspect. 33 (2), 89-114.

Saint-Paul, G., 2018, January. The possibility of ideological bias in structural macroeconomic models. Am. Econ. J. Macroecon. 10 (1), $216-241$.

Simmons, J.P., Nelson, L.D., Simonsohn, U., 2011. False-positive psychology: undisclosed flexibility in data collection and analysis allows presenting anything as significant. Psychol. Sci. 22 (11), 1359-1366. 
Sismondo, S., 2008. Pharmaceutical company funding and its consequences: a qualitative systematic review. Contemp. Clin. Trials 29 (2), $109-113$.

Stanley, T., Doucouliagos, H., Giles, M., Heckemeyer, J., Johnston, R., Laroche, P., Nelson, J., Paldam, M., Poot, J., Pugh, G., Rosenberger, R., 2013. Meta-analysis of economics research reporting guidelines. J. Econ. Surv. 27 (2), 390-394.

Stanley, T.D., 2001. Wheat from chaff: meta-analysis as quantitative literature review. J. Econ. Perspect. 15 (3), $131-150$.

Stanley, T.D., Doucouliagos, H., 2012. Meta-regression Analysis in Economics and Business. Routledge.

Tiebout, C.M., 1956. A pure theory of local expenditures. J. Polit. Econ. 64 (5), 416-424.

Tufte, E.R., 1978. Political Control of the Economy. Princeton University Press.

Vasishth, S., Mertzen, D., Jäger, L.A., Gelman, A., 2018. The statistical significance filter leads to overoptimistic expectations of replicability. J. Mem. Lang. 103, 151-175.

Young, A., 2017. Consistency without Inference: Instrumental Variables in Practical Application. Mimeo: LSE. 